\title{
EL PROBLEMA DE LA PROPIEDAD DE LA TIERRA EN EL SUR DE CHILE (1850-1930)
}

Se estudia el conflicto en torno a la propiedad de la tierra en el sur de Chile (principalmente en la Araucanía, Valdivia y Osorno), el que tuvo como protagonistas al Estado, chilenos y extranjeros. Se revisan los antecedentes del problema, especialmente la llegada de población chilena y extranjera a la zona y la presencia de comunidades indígenas, entre mediados del siglo XIX y 1929. Después, la búsqueda de una solución, a través de diversas leyes, la acción de un ministerio especial y, particularmente, la política estatal sobre comunidades indígenas. En general, se destaca el interés estatal por consolidar la propiedad rural privada, mediante el reconocimiento rápido de los propietarios con títulos y de los ocupantes efectivos y el término de las comunidades indígenas. El éxito de la labor estatal fue parcial, fortaleciendo la propiedad privada, pero sin lograr acabar con la propiedad comunitaria.

Palabras clave: propiedad de la tierra, comunidades indígenas, políticas estatales, agricultores, progreso nacional.

This paper analyzes conflicts over land ownership in Southern Chile (Araucanía, Valdivia and Osorno mainly). This conflict had as its main protagonists the State, Chileans and foreigners. After the revision of its background, including the arrival of Chileans and foreigners to the area and the presence of indigenous communities, the article pays attention to the efforts made trough legislation, ministerial work and State policies over indigenous communities to solve the problem. This reveals the attempt made by the State to consolidate rural private ownership. This was made trough expedite recognition of owners in possession of land titles and land settlers, in an effort to put an end to indigenous communities. The success was partial because communal land ownership did not disappear, despite the strengthening of private land ownership.

Key words: Land ownership, indigenous communities, State policies, farmers, national progress.

Fecha de recepción: abril 2008

Fecha de aceptación: enero 2009

* Universidad Austral de Chile. Correo electrónico: falmonac@uach.cl 


\section{INTRODUCCIÓN}

Uno de los asuntos más complejos en el sur de Chile, a partir de la segunda mitad del siglo XIX, fue el de la propiedad de la tierra. Después de un rápido establecimiento de chilenos y extranjeros, desde Arauco hasta el extremo sur del país, los problemas relacionados con la propiedad rural fueron enormes.

A comienzos del siglo XX, el tema se había transformado en un problema político y económico de relevancia. Conflictos entre individuos, desde juicios hasta hechos de sangre; el Estado defendiendo unas nunca bien definidas tierras fiscales; desalojos violentos de ocupantes por la autoridad, etc.

El ambiente se enrareció tanto que los títulos de propiedad y los derechos sobre la tierra de los particulares (chilenos y extranjeros) fueron puestos en duda, bajo la acusación de fraude, usurpación, en fin, de haberse formado por diversos medios ilegales, generalmente construidos al interior de notarías y juzgados de maneras no legítimas. Justos y pecadores terminaron puestos en el mismo grupo ${ }^{1}$.

La pérdida de legitimidad generaba efectos diversos: algunos pedían hacer vista gorda de todo lo ocurrido y reconocer los derechos que daba la ocupación efectiva, esto es, que fuera dueño de la tierra quien la trabajara, favoreciendo por ese entonces a nuevos ocupantes y propietarios, contra quienes eran dueños en los papeles y contra los indígenas, que supuestamente tenían abandonadas esas tierras. Había otros, legalistas a brazo partido, que proponían revisar los derechos de todos los propietarios y ocupantes, aunque no estaban de acuerdo en la forma de resolver el asunto. Entre estos estaban quienes suponían que el Fisco había sido afectado profundamente por la rápida ocupación y compraventa de tierras, siendo usurpadas muchas tierras fiscales. También, los que veían que las disposiciones sobre prohibición de adquirir tierras de indios o en territorio indígena habían sido burladas y querían anular dichos actos.

Con algo de exageración, Luis Urrutia Ibáñez, abogado de Valdivia, escribía en 1911 que a lo menos la mitad de los predios rústicos de las provincias de Valdivia y Llanquihue carecían de un título perfecto y eran susceptibles de litigio con el Fisco $^{2}$. Resumiendo bien los planteamientos que se imponían, señalaba:

"a primera vista no puede medirse la gravedad del mal; pero si se piensa que los terrenos cuyos títulos son litigiosos alcanzan en la provincia de Valdivia solamente a más de quinientas mil hectáreas de suelos cultivados, se ve cuanto sufre la riqueza pública y privada con dejar fuera del comercio humano y del progreso agrícola y entregada al desorden y a la violencia tan enorme extensión territorial, poblada por miles de familias, y se comprende, al mismo tiempo, cuán gigantesco paso en el camino de la prosperidad daría esta zona si una ley previsora y sabia constituyera pronta y definitivamente la propiedad raíz"3.

1 La expresión "particulares" se entiende aquí como propietarios u ocupantes no indígenas de tierras. Asimismo, para efectos prácticos, en el término "chilenos" excluimos a los indígenas.

2 Luis Urrutia Ibáñez, Estudio sobre la constitución de la propiedad raíz en la zona austral, Valdivia, Imprenta Central J. Lampert, 1911, 3.

$3 \quad$ Ibid., 8. 
A medida que el número de propietarios rurales en el sur de Chile era cada vez mayor, en las primeras décadas del XX aumentaba la convicción de que la realidad terminaría imponiéndose a lo ideal, que la fuerza de los hechos consumados se transformaría en derecho, que, en definitiva, los títulos de propiedad construidos irregularmente terminarían siendo plenamente aceptados, pues, de lo contrario, pocos saldrían libres de crítica en el sur de Chile.

En este artículo nos proponemos tratar los antecedentes de este problema, la legislación y la acción estatal para darle solución en las primeras décadas del siglo $\mathrm{XX}$, y dentro de ello, finalmente, el interés por acabar con las comunidades indígenas.

El sur considerado corresponde principalmente a las provincias de Malleco, Cautín y Valdivia (incluyendo Osorno), donde se produjeron las mayores dificultades, con algunas referencias al territorio más austral.

\section{NuEVOS Y VIEJOS DUEÑOS DE LA TIERRA, 1850-1929}

A mediados del siglo XIX se inició la llegada de inmigrantes alemanes a la provincia de Valdivia, los que se fueron estableciendo en torno a la ciudad del mismo nombre y en las zonas menos habitadas del sur, cerca de Osorno y en el lago Llanquihue. Hasta ese momento, dicha provincia contaba con una pequeña población y llevaba una vida lánguida. Mientras la Araucanía se mantuvo como territorio indígena hasta la década de 1880 , el contacto de Valdivia con el resto del país fue fundamentalmente por vía marítima. Rápidamente, Valdivia se transformó en la principal ciudad del sur de Chile y el centro de las actividades económicas regionales. En ello, los inmigrantes alemanes tuvieron un papel destacado, dedicados a la industria, comercio y agricultura. La zona comenzó a atraer cada vez más población nacional. Los indígenas fueron desplazados de las tierras más atractivas y quedaron relegados a la costa y los faldeos cordilleranos. Bajo presión, con engaños y por compras, chilenos y extranjeros se hicieron propietarios de la mayor parte de las tierras ${ }^{4}$.

Por su parte, la Araucanía fue ocupada militarmente desde la década de 1860 . Lentamente se fue avanzando la línea de frontera hasta controlar completamente la región en 1881-1883. Como han planteado José Bengoa y Jorge Pinto, la ocupación, hecha a través del saqueo, la depredación y la imposición político-militar, provocó

\footnotetext{
4 Para los aspectos generales de la historia regional valdiviana, Gabriel Guarda, O.S.B., Nueva Historia de Valdivia, Santiago, Ediciones Universidad Católica de Chile, 2001, 518-758. Respecto a los alemanes, ver Jean Pierre Blancpain, Los alemanes en Chile, 4 vols., tesis doctoral inédita, traducción Ives Yavet, s/a; y sobre la propiedad rural, Fabián Almonacid, "El desarrollo de la propiedad rural en las provincias de Valdivia y Llanquihue, 1850-1920", en Revista Austral de Ciencias Sociales 2, Valdivia, marzo-agosto de 1998, 27-36; Fabián Almonacid, "El mercado de tierras en el departamento de Valdivia, 1859-1877", Revista de Historia 8:8, Concepción, 1998, 195-206; y Fabián Almonacid, Industria, industriales y propiedad agrícola en el departamento de Valdivia, 1870-1914, tesis para optar al grado de magíster en Historia, Universidad Católica de Valparaíso, Valparaíso, 1999.
} 
una profunda transformación en la sociedad mapuche ${ }^{5}$. Detrás de estas acciones, fuera del objetivo de incorporar efectivamente estos territorios al Estado nacional y los intereses económicos implicados, había un rechazo generalizado al indio. Como dijo el diario El Mercurio en 1859, los araucanos: "no eran más que una horda de fieras que es urgente encadenar o destruir en el interés de la humanidad y en bien de la civilización"6. Tal como en Argentina, aunque con algunas voces disidentes, en Chile la llamada, eufemísticamente, "pacificación de la Araucanía" se sustentó en la barbarie del indio, en su escaso número y en el abandono en que se hallaban las tierras que ocupaban. Sin embargo, los mapuches, objetivamente, eran diferentes a los indígenas del sur argentino; asentados en el territorio, agrupados en familias, con sus campos de cultivo y pastos, casas, huertas, ganado, relaciones comerciales con chilenos, etc. Poco importaba la realidad en ese momento.

Paralelamente al inicio de la ocupación, el Estado comenzó a legislar sobre las tierras del $\operatorname{sur}^{7}$. Debido al poblamiento espontáneo de los territorios de la Araucanía y Valdivia, desde mediados del siglo XIX hubo crecientes irregularidades con la ocupación de tierras y con las compras a indígenas, por lo que desde 1852 se restringió la compraventa de terrenos indígenas, dejándola bajo la supervisión de la autoridad. Sin embargo, rápidamente esas disposiciones fueron vulneradas por la vía judicial. Una ley importante fue la del 4 de diciembre de 1866, que permitió la fundación de poblaciones en territorios indígenas, en los terrenos que el Estado poseyera y en los que adquiriera. Asimismo, el Estado vendería en subasta pública sus terrenos en lotes de 500 hectáreas. La misma ley impidió la enajenación de terrenos entre particulares en territorio indígena (la Araucanía), con la excepción de aquellos que estuvieran inscritos y registrados. Además, ordenó que una comisión procediera al deslinde de los terrenos pertenecientes a indígenas, dándole a estos un título de merced por esas tierras a nombre de la república ${ }^{8}$.

Detrás de esta decisión estaba el interés por "reducir" a los mapuches en las menores tierras posibles y liberar el resto del territorio para el establecimiento de chilenos y extranjeros. Más aún, se declaraban "terrenos baldíos", por lo tanto estatales, todos aquellos en los cuales los indígenas no pudieran probar una posesión efectiva y continuada de a lo menos un año.

5 José Bengoa, Historia del pueblo mapuche. Siglo XIX y XX, Santiago, Lom Ediciones, 2000, 178-326; y Jorge Pinto, De la inclusión a la exclusión. La formación del Estado, la nación y el pueblo mapuche, Santiago, Instituto de Estudios Avanzados, Universidad de Santiago de Chile, 2000, 109-206.

6 Citado en Pinto, De la inclusión a la exclusión..., op . cit., 132.

7 Los mejores escritos sobre legislación de tierras y evolución de la propiedad fiscal, indígena y particular a principios del siglo XX son los de Agustín Torrealba, Tierras fiscales en las provincias de Valdivia y Llanquihue, memoria presentada a la Inspección General de Tierras y Colonización, Santiago, Imprenta Cervantes, 1907; Tierras del Estado y radicación de indígenas, apuntes para la nueva legislación, proyecto de ley para constituir la propiedad en las provincias australes..., Santiago, Imprenta Barcelona, 1908; La propiedad fiscal y la particular en las provincias australes, segunda parte, Santiago, Imprenta Universitaria, 1916; y Tierras fiscales y de indígenas. Su legislación y jurisprudencia, Santiago, Imprenta Universitaria, 1917. Además, ver Instituto Nacional de Asuntos Indígenas, Recopilación de la legislación indígena chilena, Temuco, inédito, 1982.

8 Instituto Nacional de Asuntos Indígenas, op. cit., 15-17. 
La misma ley establecía la forma de definir las tierras indígenas. Se les entregarían títulos a los que demostraran ocupación efectiva y continuada; si varios indígenas pretendieren un terreno, se favorecería al que lo hubiera ocupado en los últimos cinco años; si varios indígenas poseyeren un mismo terreno, se les consideraría comuneros y se les dividiría en partes iguales; todos los derechos de propiedad se le reconocerían al cabeza de familia (varón o mujer); si los indígenas poseyeran un terreno como reducción dependiente de un cacique, se les daría la propiedad en común; si una octava parte de los jefes de familia de una reducción quisieren que se les otorgase la propiedad por separado, se haría la división, dando al cacique el triple de terreno que se les asignase a los cabezas de familia; y se preferirían los límites naturales para deslindar las propiedades.

Como se ve, la ley de 1866 daba la opción a los indios de obtener títulos por familias o por comunidades (la expresión no aparece en la ley; se habla de reducciones). Evidentemente, la exigencia de "ocupación efectiva y continuada" era una sutil expresión que impediría a los indígenas reclamar derechos sobre muchas tierras que habían ocupado por largo tiempo, pero en las cuales (especialmente, bosques y pastos) hacían un uso esporádico. La restricción del legislador los terminaría reduciendo a la propiedad de sus casas, huertas y campos de cultivo. Sin embargo, el carácter principalmente ganadero y comerciante del pueblo mapuche quedaba fuera de las consideraciones de la ley.

No fue sino hasta 1883 cuando comenzó a implementarse esa disposición, tras la creación de la Comisión Radicadora. Las reglas que seguiría en su cometido fueron las establecidas en 1866. Así, desde 1884 comenzó el lento trabajo de la comisión, que recién concluyó en 1929.

La demora en implementar la comisión señalada facilitó la pérdida de tierras por los indígenas. Eran tales los abusos cometidos, que escandalizaban a las propias autoridades establecidas en la zona, que el 4 de agosto de 1874 se prohibió a los particulares la adquisición de terrenos indígenas, entre el río Malleco y el límite norte de la provincia de Valdivia, es decir, en toda la Araucanía, excepto de las propiedades ya inscritas en forma legal, con lo que el Estado pasó a ser casi el único vendedor de tierras.

La medida no afectaba a la provincia de Valdivia. El mercado de tierras fue muy activo allí por este tiempo. Mientras entre 1788 y 1870 solo se inscribieron 344 escrituras por compraventa de tierras en la notaría de la ciudad de Valdivia, desde 1870 a 1907 fueron más de siete mil, de las cuales unas mil fueron otorgadas por indígenas. Las propiedades vendidas en muchos casos correspondían a extensas zonas, sin límites precisos ${ }^{9}$. A lo anterior habría que sumar todas las ocupaciones de hecho, para considerar el avance que tuvo la propiedad rural privada en manos de particulares en esta zona, en desmedro de los intereses fiscales e indígenas. Recién el 11 de enero de 1893 se extendió la prohibición de adquirir terrenos indígenas desde la provincia de Valdivia al sur.

9 Torrealba, La propiedad fiscal..., op . cit., 130. 
En todo caso, por esta fecha la mayor parte de las tierras de calidad ya habían sido obtenidas por particulares, por lo que la decisión fue poco efectiva en la práctica, ya que no afectaba a las propiedades adquiridas con anterioridad. Además, siempre fue posible vulnerar la ley aduciendo que el vendedor no era indígena. Las leyes dictadas hasta la fecha no definían, y no lo hicieron por mucho tiempo, quiénes eran indígenas. Así, todo quedaba librado al criterio de los jueces, los que entendían que aquellos mapuches que ejercían sus derechos ciudadanos o estaban educados ya no eran indígenas, como le ocurrió a Joaquín Millanao, que perdió sus tierras en el norte de la provincia de Valdivia, por una decisión de este tipo en $1895^{10}$.

De este modo, por las leyes de 1874 y 1893, en toda la Araucanía y Valdivia se prohibió la compra de tierras a indígenas. La medida, según la ley de 1893, regiría por diez años, siendo prorrogada en 1903 por otro periodo similar y nuevamente en 1913, hasta que hubiera una nueva ley sobre la propiedad indígena, que se dictó recién en 1927. Por ello, la forma de adquirir tierras fue directamente del Estado, por remates de hijuelas o por concesión, o de particulares cuyos títulos fueran anteriores a las fechas señaladas. Efectivamente, en el último caso, existían, y siguieron existiendo, muchos títulos fabricados en las notarías de la zona, cuyo valor real era escaso, ya sea porque el vendedor no era el dueño, porque se vendía una cantidad mayor de la que efectivamente se poseía o porque los límites dados eran imprecisos, entre otras razones.

Por todo ello, una forma recurrente para expandir las propiedades rurales fue la vía de los hechos consumados; expulsando a los indígenas u otros ocupantes por la fuerza, corriendo cercos, arrendando terrenos y después haciéndose dueño de ellos, prestando dinero a los indígenas y después quitándoles sus tierras y bienes judicialmente, etc. La ley del más fuerte era la única que imperaba en los campos de la Araucanía y Valdivia ${ }^{11}$.

El Estado hizo bien poco para evitar todo ello. La radicación de los indígenas avanzó lentamente, generalmente detrás de las usurpaciones de tierras cometidas por particulares, cuando ya los indios habían sido desplazados a los peores terrenos. La comisión encargada de radicar a los indígenas comenzó su labor en la Araucanía, en la que concedió títulos de merced desde 1884. Sin embargo, recién a principios del siglo XX pasó a trabajar desde Valdivia al sur, cuando ya era muy tarde. Excepto los títulos entregados en la parte norte de la provincia de Valdivia, desde esta provincia al sur ya no había terrenos donde radicar a los indios, por lo que su labor fue muy escasa allí. En esa zona los indígenas permanecerían como simples ocupantes o como inquilinos en propiedades particulares.

Como se ve en el cuadro $\mathrm{N}^{\circ} 1$, entre 1884 y 1929, la comisión entregó un poco más de tres mil títulos, por cerca de 500 mil hectáreas, a unos 90 mil indígenas. La

10 Torrealba, Tierras fiscales y de indígenas..., op. cit., 293-298. Una supuesta deuda de 160 pesos de Millanao a Rafael Reyes, le hizo perder un fundo que valía 30 mil pesos, en 1905. Sigifredo Schneider de Fraunhäusl, R.P., Crónica de la Misión de San Sebastián de Panguipulli, primer libro 1903-1924, texto mimeografiado, Temuco, Museo Regional de la Araucanía, 1924, 22.

11 Tomás Guevara, Costumbres judiciales y enseñanzas de los araucanos, Santiago, Imprenta Cervantes, 1904, 53-59. El autor da ejemplos de diversas formas que se usaban para apropiarse de terrenos indígenas, similares a las mencionadas en el texto. 
mayor parte de los radicados y tierras indígenas se encontraban en la provincia de Cautín, seguida por Malleco y Valdivia. Tanto al norte de Malleco como al sur de Valdivia los títulos de merced fueron escasos.

\section{CUADRO N ${ }^{\circ}$}

TÍTULOS DE MERCED ENTREGADOS POR LA COMISIÓN RADICADORA, 1884-192912

\begin{tabular}{|c|c|c|c|}
\hline Provincia & $\mathrm{N}^{\mathrm{o}}$ reducciones & Hectáreas & $\mathrm{N}^{\mathrm{o}}$ de personas \\
\hline \multicolumn{4}{|l|}{ Biobío } \\
\hline \multicolumn{4}{|l|}{ Departamento } \\
\hline Mulchén & 6 & 659 & 118 \\
\hline \multicolumn{4}{|l|}{ Arauco } \\
\hline \multicolumn{4}{|l|}{ Departamento } \\
\hline Cañete & 66 & $7.115,59$ & 1.912 \\
\hline \multicolumn{4}{|l|}{ Malleco } \\
\hline \multicolumn{4}{|l|}{ Departamento } \\
\hline Victoria & 38 & 8.410 & 1.438 \\
\hline Traiguén & 183 & $53.656,75$ & 7.067 \\
\hline Collipulli & 82 & 12.605 & 1.716 \\
\hline Angol & 47 & $8.869,5$ & 1.291 \\
\hline Subtotal provincia & 350 & $83.541,25$ & 11.512 \\
\hline \multicolumn{4}{|l|}{ Cautín } \\
\hline \multicolumn{4}{|l|}{ Departamento } \\
\hline Temuco & 603 & $104.653,3$ & 22.079 \\
\hline Lautaro & 171 & $29.852,2$ & 3.781 \\
\hline Nueva Imperial & 719 & $115.851,6$ & 22.935 \\
\hline Pitrufquén & 304 & $41.653,4$ & 7.251 \\
\hline Villarrica & 305 & $47.858,48$ & 7.566 \\
\hline Subtotal provincia & 2.102 & $339.868,98$ & 63.612 \\
\hline \multicolumn{4}{|l|}{ Valdivia } \\
\hline \multicolumn{4}{|l|}{ Departamento } \\
\hline Valdivia & 410 & $64.512,6$ & 9.502 \\
\hline La Unión & 15 & 422 & 101 \\
\hline Río Bueno & 87 & $5.125,5$ & 1.737 \\
\hline Osorno & 40 & 3.450 & 1.828 \\
\hline Subtotal provincia & 552 & $73.510,1$ & 13.168 \\
\hline \multicolumn{4}{|l|}{ Llanquihue } \\
\hline \multicolumn{4}{|l|}{ Departamento } \\
\hline Llanquihue & 2 & 83,5 & 29 \\
\hline Total & 3.078 & $504.778,42$ & 90.401 \\
\hline
\end{tabular}

12 Dina Muñoz Bayer, Comunidades Indígenas, Temuco, Imprenta y Editorial Gutiérrez, 1948, 39. Los datos consignados son similares a los publicados por Alejandro Lipschütz, La comunidad indígena en América y en Chile, Santiago, Editorial Universitaria, 1956, 141, pero algo distintos a la mayoría de los citados por otros autores, producto de las diferencias que ofrecen los propios datos entregados por las autoridades de la época. 
Si se compara el número de hectáreas con la población indígena, se obtiene una cifra muy baja de tierras por persona (en total unas 5,58 hectáreas en promedio), lo que muestra la estricta aplicación que se hizo de la ley de 1866, en cuanto a la "ocupación efectiva y continuada". Respecto al tamaño promedio de las reducciones, iban desde las 60 hectáreas en la parte sur de la provincia de Valdivia, hasta cerca de 110 hectáreas en las provincias de Arauco y Biobío, bordeaban las 160 hectáreas en el departamento de Valdivia (al norte de la provincia) y en la provincia de Cautín, y se acercaban a las 240 hectáreas en Malleco. Muchas de las tierras entregadas estaban ubicadas en zonas costeras y cordilleranas; tierras de mala calidad, de difícil acceso y comunicación. En todo caso, también las había, en menor medida, en torno a las nuevas ciudades y en terrenos aptos para la agricultura, en Malleco, Cautín y Valdivia.

Considerando las provincias señaladas en el cuadro $\mathrm{N}^{\circ} 1$, desde Biobío hasta Llanquihue, cuya superficie total era de 9,5 millones de hectáreas, se observa que solo una ínfima parte de ellas quedó en manos indígenas ${ }^{13}$.

En cuanto a la forma en que fueron radicados los indígenas, aunque la ley de 1866 permitía que hubiera radicación familiar o comunitaria, la comisión se decidió mayoritariamente por la segunda, pero tal como ella la entendía, sin respetar la organización mapuche tradicional, formada por familias extensas y linajes; esto hubiera requerido conceder menos títulos, a nombre de los principales jefes indígenas, que no pasaban del centenar en todo el $\operatorname{sur}^{14}$. Pero lo que se quería no era eso, sino la fragmentación de la sociedad mapuche y su rápida integración a la sociedad nacional. Por ello fueron dados títulos a nombre de los caciques locales (jefes de familia), bajo los que se colocó a su familia y a otras del lugar.

De este modo se formó una "comunidad" donde no la había. Muchas veces, caciques menores pasaron a recibir título de merced, por sobre otros caciques del lugar ${ }^{15}$. A veces el simple hecho de saber hablar en castellano les dio a algunos la

13 Ivo Babarovic et al., Campesinado mapuche y procesos socio-económicos regionales, Santiago, Grupo de Investigaciones Agrarias, Academia de Humanismo Cristiano, 1987, 61. Según José Aylwin y Martín Correa, utilizando datos diferentes a los nuestros, las tierras que incluían los títulos de merced correspondían al 6,03\% de la superficie de la provincia de Malleco, al 17,72\% de la provincia de Cautín y al 3,85\% de la provincia de Valdivia. Considerando desde Biobío hasta Osorno, los indígenas recibieron el 6,39\% de la superficie. Véase Comisión Verdad Histórica y Nuevo Trato a los Pueblos Indígenas, Informe final, en www.gobierno.cl/verdadhistorica/presentacion.html

14 Para esta parte, Comisión Verdad Histórica y Nuevo Trato, op. cit.; Bengoa, Historia del pueblo mapuche..., op. cit., 354-362; y José Bengoa y Eduardo Valenzuela, Economía mapuche. Pobreza y subsistencia en la sociedad mapuche contemporánea, Santiago, PAS, 1984, 38. Estos señalan que en la Araucanía, en la primera mitad del siglo XIX, había entre 20 y 30 caciques principales.

15 Fray Félix José de Augusta, Lecturas araucanas. Autorretrato del araucano. Vetera et nova, colaboración de Fray Sigifredo de Fraunhäusl, segunda edición, Padre Las Casas, Imprenta y Editorial San Francisco, 1934, 53-55. Esta obra, publicada por primera vez en 1910, recoge el testimonio de una mujer mapuche en 1898, que señala que el hombre que recibió el título de merced no era el cacique más importante del lugar, quien amenazó a los "mocetones" del lugar para que no pidieran tierras por separado de él. El marido de la mujer, ya difunto, antes había sido jefe de muchos terrenos y cuando murió, el otro cacique la dejó solo con unos terrenos de montaña, muy pocos. Además, el cacique dominante le pedía dinero a las familias para, según él, viajar a pedir más tierras, pero al parecer ello no ocurrió nunca. 
calidad de cacique. Por último, estas agrupaciones arbitrarias colocaron en "igualdad" de condiciones a los caciques tenedores de los títulos de merced, a pesar de que entre los mapuches se distinguía entre caciquillos y caciques principales. Algunos que no eran más que "mocetones", nombre dado al mapuche común, pobre, fueron puestos a la misma altura de un cacique principal, lo que para este era insoportable, en su calidad de "ulmen" (hombre rico y respetado).

Los títulos fueron emitidos a nombre del jefe de familia, con la mención de todos los indígenas mayores (varones y mujeres) radicados en tal lugar, por lo que la propiedad de las tierras era común. El tamaño de la propiedad variaba según el lugar, mientras mejores fueran las tierras se otorgaba una menor cantidad, y el número de personas. En algunos casos, al parecer los menos, a petición de los propios indígenas se dio título de merced a nombre de una familia nuclear (padre, madre e hijos), generalmente cuando había diferencias considerables entre las familias del lugar. También hubo algunos caciques principales que, habiendo apoyado la acción del Gobierno en la zona, recibieron títulos a su nombre, por separado.

El cacique a nombre del cual se entregó el título de merced quedó en una posición favorable dentro de su reducción, por lo que las mejores tierras fueron para sus más cercanos.

La radicación constituyó un cambio sustancial en la organización social mapuche. Impedidas las relaciones de linaje, disminuido el espacio de existencia al mínimo, la reducción pasó a ser la unidad fundamental para la vida mapuche. Generalmente, cada reducción era una comunidad, por lo que en la práctica ambas expresiones pasaron a ser sinónimas, y la segunda fue reemplazando a la primera. Sin embargo, seguramente por la radicación en grupos familiares menores, hubo lugares donde varias reducciones se consideraban parte de una misma comunidad, por lo que mantenían diversos vínculos que los relacionaban (ceremonias, trabajos conjuntos, parentesco, etc.).

Por otro lado, por los desplazamientos provocados por el Estado y los particulares y la demora en la radicación, muchos mapuches recibieron tierras finalmente en lugares distintos al de origen, por lo que los vínculos entre los indígenas que habitaban un mismo lugar a veces eran escasos o conflictivos. Hoy todavía muchos descendientes recuerdan que sus familias habían llegado poco antes de ser radicados, huyendo de los "huincas". En una comunidad de la provincia de Cautín, a fines de la década de 1980, un indígena recordaba:

"toda la gente era de por allá [de Contulmo, provincia de Arauco]. Porque tenían un pedacito de tierra los atrincaron los chilenos y tuvieron que venirse. Mi padre me lo contaba; ya por el año 1915 yo tenía conocimiento de las cosas, mi padre debe haber llegado por aquí por 1890. En ese tiempo había una vieja indígena que mandaba a todos aquí... Ella nos quería correr, que nos fuéramos de acá... Pero como esta era tierra fiscal, nadie nos podía correr"16.

16 Babarovic et al., op. cit., 176. 
Dadas las características señaladas, los vínculos comunitarios al interior de cada reducción fueron cada vez más débiles. El poder del cacique tendió a disminuir, ya no era necesaria su representación, y los miembros de la comunidad se dirigían directamente a las autoridades nacionales. Asimismo, en la práctica, cada familia que integraba una comunidad, en función de su mención en el título de merced, recibió el goce de una parte de las tierras de la reducción, la que generalmente fue heredándose al interior de esa familia, sin volver al conjunto de la comunidad $^{17}$.

Detrás de la acción estatal estaba la indiferencia por la suerte del indígena. Muchos estaban convencidos que no podría sobrevivir al avance del "progreso", por lo que se entiende que la radicación no fuera realizada con demasiado esmero. Luis Riso Patrón, funcionario de la Oficina de Mensura de Tierras, escribía al ministro de Relaciones Exteriores, de quien dependía esa actividad, el 19 de junio de 1908, respecto a los abusos contra los mapuches:

“evitar que los indígenas no se vean expoliados no está en manos del infrascrito, ni creo que nadie pueda evitarlo, a pesar de la promulgación de nuevas leyes de protección, como quiera que se trata de una raza inferior, en consecuencia dirigiré mis esfuerzos en este ramo, a lo único posible dentro de la esfera de mi acción; poner en manos de cada familia indígena, tan pronto como las circunstancias lo permitan, su respectivo título de merced, con el que podrán hacer frente a los que pretendan adueñarse de sus tierras"18.

El interés estatal estuvo concentrado en establecer chilenos y extranjeros en la zona. Comparando, es notable la diferencia establecida por el Estado entre indígenas y rematantes de tierras fiscales, en el acceso a la tierra. Mientras a los indígenas se les daba lo mínimo necesario, se remataban hijuelas de 500 hectáreas, las que muchas veces eran adquiridas en cantidad numerosa por una misma persona. Entre 1873 y 1915 se remataron en las provincias de Malleco y Cautín 1.213.816 hectáreas ${ }^{19}$.

Además, se establecieron colonos en la zona. En Malleco, entre 1882 y 1915, el Estado donó, a 870 familias de colonos extranjeros, 51.118 hectáreas; en Cautín, en los mismos años, a 459 familias, 26.208 hectáreas; y en Valdivia, entre 1850 y 1915, a 573 familias, 25.575 hectáreas. También hubo chilenos que recibieron tierras como colonos: en Malleco y Cautín, desde 1896 a 1915, se establecieron 2.502 familias en 149.245 hectáreas. La superficie de las hijuelas dada a estas familias era sustancialmente mayor que la otorgada a los indígenas. Asimismo, cada propiedad de los colonos agrupaba solo al padre, madre e hijos, y recibían apoyo estatal para establecerse en las mejores condiciones ${ }^{20}$.

17 Tomás Guevara, Las últimas familias y costumbres araucanas, Santiago, Imprenta, Litografía y Encuadernación Barcelona, 1913, 195-221.

18 Citado por Almonacid, "El desarrollo de la propiedad rural...", op. cit., 34.

19 Datos en Torrealba, La propiedad fiscal...., op. cit., 30, 36-37, 43, 51, 62 y 91.

20 Véase el caso de la colonia Nueva Transvaal en Gorbea, provincia de Cautín, en Christian Martínez y Gerardo Bohle, La colonia Nueva Transvaal: colonización holando boers en la Araucanía, Gorbea 1903-1913, seminario de titulación, Universidad de La Frontera, Temuco, 1989. 
Por otro lado, a comienzos del siglo XX, el Estado dio títulos a 773 familias ocupantes por 32.593 hectáreas, especialmente en la provincia de Valdivia.

A principios del siglo XX el Estado cedió la actividad colonizadora a particulares, entregando a 8 empresas colonizadoras en las provincias de Malleco, Cautín y Valdivia 213.945 hectáreas, con el fin de establecer colonos. Los resultados fueron escasos. Unas 363 familias de colonos fueron establecidas entre Malleco y Valdivia en 28.165 hectáreas. El resto de los terrenos quedaron como beneficio de las sociedades de colonización.

El establecimiento de colonos fue hecho torpemente, afectando a ocupantes chilenos o a indígenas que habían recibido títulos de merced en los mismos terrenos que eran entregados a colonos o a las empresas colonizadores. Ocurrió con la concesión de 56.025 hectáreas que recibió la sociedad E. Domínguez y Compañía en la zona costera de la provincia de Cautín; con la concesión de 24.415 hectáreas que recibió la sociedad Comunidad Llaima en la cordillera de la misma provincia; y con la concesión de 75.000 hectáreas a la sociedad Ricci Hermanos y Compañía en la provincia de Malleco ${ }^{21}$. En todos los casos hubo conflictos importantes.

En total, todos los terrenos enajenados por el Estado (colonos, ocupantes, empresas de colonización y otros), excluyendo los dados a indígenas, en las provincias de Malleco, Cautín y Valdivia, desde 1850 hasta 1915, llegaron a 1.754 .003 hectáreas. Esta era una cifra más de tres veces superior a la cantidad recibida por los indígenas.

Si se comparan esos datos con la superficie efectiva de las propiedades rurales de las tres provincias, un poco más de 2,9 millones de hectáreas en 1915, se deduce que una parte importante de las propiedades rurales no tuvieron su origen en la acción estatal. En el caso de Malleco y Cautín casi toda la propiedad se originaba en lo hecho por el Estado, mientras que en Valdivia, de un total 1.555.600 hectáreas de propiedades rurales, solo 352.533 hectáreas provenían del Estado. El resto correspondía a compraventas entre particulares. Por ello, las irregularidades cometidas en la formación de los fundos particulares eran considerablemente mayores en Valdivia que en las otras dos provincias.

En lo esencial, a pesar de algunas experiencias protoindustriales, la región estudiada se organizó principalmente en torno a las actividades agropecuarias, por lo que la propiedad de la tierra se transformó en un recurso fundamental para el desarrollo regional ${ }^{22}$. Con un Estado débil y pasivo, los chilenos y extranjeros fueron estableciéndose con el consiguiente perjuicio para los indígenas. Resultado de todo ello, hubo una creciente conflictividad en torno a la tierra, pues se utiliza-

21 Sobre la sociedad E. Domínguez y Cía., véase Florencia Mallon, La Sangre del Copihue. Comunidad mapuche Nicolás Ailío y el Estado chileno, 1906-1996, Santiago, Lom Ediciones, 2004, 50-53, quien señala que tras varias dificultades la sociedad fracasó en su empeño, quedando 13.597 hectáreas en manos de colonos e indígenas y las 42.068 hectáreas restantes para la sociedad, por cuatro años de "trabajo". Sobre Nueva Italia, aunque menos graves, pueden verse algunos conflictos en Baldomero Estrada, "Colonización y civilización europea en la Frontera: el caso de la colonia Nueva Italia”, en Jorge Pinto Rodríguez (ed.), Araucanía y pampas. Un mundo fronterizo en América del Sur, Temuco, Ediciones Universidad de La Frontera, 1996, 239-267.

22 Ver Almonacid, Industria, industriales y propiedad..., op. cit. 
ban todo tipo de argucias para apropiarse de los mejores terrenos. Conatos de violencia, asesinatos, expulsión de ocupantes e indígenas, remates de tierras amañados para favorecer a ciertos personajes, en fin, la fuerza y el engaño fueron las vías predilectas para generar derechos sobre la tierra.

En 1901 un funcionario de la Inspección de Tierras y Colonización denunciaba:

"son muchas las personas que hay en Valdivia, sindicadas de haber asesinado a indios, casi me atrevo asegurar que nunca se ha levantado un sumario para esclarecer la verdad; pero sí aseguro que estos son ricos propietarios, dueños de considerables extensiones de terrenos que antes ocupaban los indios" 23 .

La zona de Panguipulli, en la cordillera de la provincia de Valdivia, es un buen ejemplo de la crueldad que adquirían los abusos cometidos contra los indígenas. Cuando todavía no se hacía allí la radicación, a principios del siglo XX, los indígenas eran objeto de todo tipo de acciones; quemas de rucas; desalojos por la fuerza; asesinatos; peleas a palos y balazos; falsas deudas que después permitían el embargo de tierras; demandas judiciales perdidas por los indígenas; ventas de chilenos a extranjeros de terrenos de indígenas; amparo y participación de las autoridades en la usurpación de tierras, etc. ${ }^{24}$. Un ejemplo de lo anterior: en marzo de 1905 dos indígenas vendieron 80 hectáreas a Pedro Castelblanco, un conocido vecino de la zona. Este, aprovechando que su hermano Plácido era notario interino en Valdivia, hizo una escritura por 7 mil hectáreas. Después de varias ventas entre chilenos, para "legalizar" el título, y acuerdos con los indígenas del lugar, a los que nunca pagó nada, terminó quedándose con 2.500 hectáreas ${ }^{25}$.

A principios del siglo XX las autoridades nacionales y locales, las iglesias, la prensa y los afectados, permanentemente denunciaban y se sorprendían del cúmulo de irregularidades que rodeaba el dominio de las propiedades rurales en el sur de Chile. El asunto se fue paulatinamente transformando en una polémica nacional. Los indígenas recurrían a los tribunales de justicia, demandaban el amparo de los misioneros capuchinos establecidos en la zona, acudían a las autoridades gubernamentales e incluso no dudaban de visitar al propio Presidente de la República. Pero no hubo un cambio significativo.

Reflejando la situación de los indígenas, en 1910, fray Félix José de Augusta salía a la defensa de ellos escribiendo:

“esta nación, hoy día tan despreciada por cierta clase de personas que desean y proponen el secuestro de sus bienes y hasta el exterminio de su raza, esta nación vive, piensa, ama, tiene sus leyes tradicionales, sus ideas religiosas, su culto, poesía, elocuencia, sus

23 Citado por Guevara, Las últimas familias..., op . cit., 218.

24 Schneider de Fraunhäusl, R.P., op. cit.

25 Ibid., 20-21. Para Panguipulli, Aurelio Díaz, En la Araucanía. Breve relación del último parlamento araucano de Coz-Coz, en 18 de enero de 1907, Santiago, Imprenta El Diario Ilustrado, 1907, recoge los testimonios de un parlamento que reunió cerca de 2 mil indígenas, en Coz-Coz (Valdivia), en enero de 1907, para compartir los atropellos de que eran objeto. 
canciones, su música, sus artes, sus fiestas y juegos, su vida cívica, sus pasiones y virtudes [...] el araucano no es el hombre brutal cual se muestra en las cantinas de la Frontera, donde de los pechos de la decantada civilización chupa el veneno mortal que destruye su raza. Al juzgar sobre el derecho de existencia se suele tomar como piedra de toque la cuestión: ¿De qué sirve el indio para el acrecentamiento nacional? Este criterio es enteramente falso [...] ellos tienen todas las disposiciones indispensables para el progreso de su nación en el sentido de la cultura y civilización. Hay que evitar los extremos y las exageraciones; ni la admiración excesiva, ni el desprecio infundado de este pueblo conducen a la realidad de los hechos. Encuéntrase entre los araucanos toda clase de caracteres e individuos de aptitudes muy diversas; existen personas de talento sobresaliente y otras de muy poca capacidad; unos son laboriosos, otros perezosos; hay ladinos y engañadores, pero también no pocos que por lo recto de su proceder, lo despierto de su genio, la sencillez y pureza de sus costumbres se hacen acreedores a la estimación y cariño de todos" 26 .

Además, reconocía Augusta que los araucanos estaban cambiando y confiaba en que pronto abandonarían sus costumbres y creencias menos tolerables.

Efectivamente, la labor de los misioneros, franciscanos hasta mediados del siglo XIX, reemplazados en adelante por capuchinos italianos y españoles, y desde 1896 por capuchinos alemanes, constituyó el principal contacto positivo de los indígenas con la cultura occidental ${ }^{27}$.

Tras la ocupación de la Araucanía, el interés de los caciques indígenas por tener a los misioneros capuchinos a su lado aumentó, pensando seguramente que su ayuda les sería útil. Caciques que sistemáticamente se habían negado a aceptarlos, ahora los llamaban, con lo que aumentó rápidamente la presencia misionera en la zona. Posteriormente, en la medida que muchos de los engaños que sufrirían a manos de "huincas" eran por no saber castellano, muchos comprendieron el valor de la escuela y comenzaron a enviar a sus hijos a ellas ${ }^{28}$.

En 1907 los capuchinos realizaron un censo de la población indígena, llegando a contar 101.112, desde la provincia de Arauco hasta la de Llanquihue. En las provincias que nos interesan se encontraba la mayoría: en Malleco 11.261, en Cautín 46.761 y en Valdivia 26.134.

La competencia por la educación de los indígenas fue creciendo. A principios del siglo XX comenzaron a establecerse las primeras escuelas fiscales entre los indígenas. Pero la labor estatal siguió siendo escasa. En 1913 un padre escribía al Gobierno: "para la civilización de la Araucanía necesitamos escuelas, escuelas y otra vez, escuelas" 29 . Sin embargo, al parecer el Gobierno no tenía la misma prisa

26 De Augusta, op. cit., 2.

27 Para esta parte, Jorge Pinto Rodríguez et al., Misioneros en la Araucanía, 1600-1900. Un capítulo de historia fronteriza en Chile, Bogotá, CELAM, 1990, vol. II: Documentos; Jorge Pinto, "Misioneros italianos en la Araucanía, 1600-1900. Evangelización e interculturalidad", en Baldomero Estrada (ed.), Presencia italiana en Chile, Valparaíso, Universidad Católica de Valparaíso, 25-59; y Albert Noggler, Cuatrocientos años de misión entre los araucanos, Padre Las Casas, Editorial San Francisco, s/a.

28 Noggler, op. cit., 109, 123, 150 y 167.

29 Ibid., 176. 
por fundarlas. Así, los misioneros aumentaron las suyas. En 1920 había 38 escuelas misionales capuchinas y 19 internados, para un total de 3.005 alumnos. En 1925 eran 39 las escuelas, dos de ellas superiores y una profesional, con 3.174 alumnos. En 1928 el número de alumnos llegaba a 4.758 .

Además de los abusos que cometían los particulares, la escuela era una experiencia más de frustración para los mapuches. Como recordaba Martín Alonqueo, quien ingresó a los 14 años a una escuela fiscal, en 1923, los profesores y los alumnos chilenos no tenían ningún respeto hacia el indígena. Para muchos de ellos, que no hablaban castellano, era un trauma llegar a ese lugar, no saber expresarse y ser motivo de burla por lo mismo ${ }^{30}$.

Martín Alonqueo, que llegaría a ser profesor y dirigente mapuche, recordaba en los años sesenta que, por los años 1919-1920, él fue testigo de cómo unos comerciantes y el juez de Padre Las Casas, cerca de Temuco, se confabulaban para robar sus bienes a los indígenas; se trataba de crear una "deuda" y pedir al juez el embargo por falta de pago. Este enviaba a la policía y el indígena perdía sin mayor trámite animales y otros bienes. En el caso recordado por Alonqueo, el lonco debió "reconocer" la deuda y terminó perdiendo parte de sus animales. El juez sancionó el acuerdo. Tal forma de fraude era ya normal para los indígenas. En otros casos, se cobraban cantidades exageradas por algunos productos dados a crédito por los comerciantes; a un tío de su abuela le habían quitado veinte animales por 2 kilos de yerba, 1 kilo de azúcar y 1 cántaro de vino. Los engaños sistemáticos de que eran objeto y la falta de apoyo de las autoridades, según cuenta Alonqueo, terminaron minando la personalidad de los indígenas:

"estos hechos paulatinamente se tradujeron en angustias, desesperación, miserias y descalabros económicos que produjeron una psicosis colectiva, incertidumbre y desconfianza en la mente de los mapuches, que se tradujeron en su propio desprecio, dando nacimiento al odio a su propia cultura e idioma" 31 .

Por otro lado, en 1896, misioneros protestantes se establecieron en la Araucanía y rápidamente fundaron escuelas en Quepe y en Cholchol. En enero de 1902, Guillermo Wilson, encargado del colegio de Cholchol, escribía al protector de indígenas, Eulogio Robles, respecto a la situación de los indígenas:

"en cuanto a los abusos y arbitrariedades cometidas contra ellos, son innumerables, y sería muy difícil precisarlos, por cuanto los explotadores siempre dan cierto viso de legalidad a sus actos, siendo en su mayoría tinterillos y comerciantes de baja ley; pero nos consta y es la voz pública que los indígenas son vergonzosamente robados y explotados en mil maneras. El alcoholismo es el factor más poderoso en la explotación de los naturales, y causa lástima y horror ver las tabernas y chincheles diariamente atestados

30 Martín Alonqueo, Mapuche, Ayer-hoy, Padre Las Casas, Editorial San Francisco, 1985, $157-$ 161. El texto fue escrito en 1960, como memoria para obtener el título de profesor primario, al que se agregaron otras informaciones en 1977 y fue publicado en 1985.

31 Ibid., 155. 
de mapuches en estado de ebriedad y allí en este estado los hacen firmar documentos, vender sus granos en yerba a precios exiguos y les arrebatan criminalmente todo cuanto pueden. El alcoholismo ha embrutecido a esta noble raza, y si no se pone remedio a este estado de cosas, ella será pronto extinguida" 32 .

La preocupación de Wilson tenía base real, pero a la vez correspondía a uno de los aspectos del interés anglicano; la disciplina personal. Ellos promovían la abstinencia alcohólica. Para los capuchinos ello no era tan relevante; incluso ellos mismos eran consumidores de alcohol. Pero anglicanos y capuchinos tenían diferencias mayores. Mientras los primeros eran más tolerantes con las costumbres indígenas, no estaban obsesionados por la inserción del indígena en la sociedad nacional y eran partidarios de la permanencia de las comunidades indígenas; los capuchinos estaban por la rápida integración del indígena al país, por su civilización bajo los dictados del cristianismo y, por lo tanto, se opusieron en su momento a la permanencia de las comunidades indígenas. Por lo mismo diferían en el tipo de educación entregada; más práctica e industrial la dada por los anglicanos, más moral y espiritual la de los capuchinos.

En la región, era claro el deseo de hacer desaparecer rápidamente a los indígenas, en cuanto grupo que vivía al margen de la "civilización" imperante. Había que educarlos, hacerlos ciudadanos, comprometerlos con el matrimonio monógamo, darles títulos de propiedad individual, etc. Si en el camino se producían algunos problemas, era un asunto menor comparado con los beneficios que se esperaba llegarían con el progreso de la región.

La situación de los indígenas estaba directamente relacionada con los intereses en torno al dominio de los recursos naturales en el sur. En esto era central la propiedad de la tierra, por lo que las decisiones tomadas por el Estado en este ámbito fueron gravitantes.

\section{LA COMISIÓN PARLAMENTARIA, 1910-1912}

Después de años de indiferencia estatal a los abusos cometidos contra los indígenas y a las irregularidades en la formación de las propiedades rurales, recién en diciembre de 1910 hubo una reacción de importancia. Tras un nuevo conflicto entre ocupantes y propietarios de tierras en Loncoche, al norte de la provincia de Valdivia, que se sumaba a una serie de quejas recibidas, la Cámara de Diputados formó una comisión para estudiar la situación de la propiedad de la tierra en el sur de Chile: colonización, indígenas y tierras fiscales ${ }^{33}$. La comisión estuvo en el sur, entre el 14 de febrero y el 2 de marzo de 1911; se entrevistó con autoridades y afectados, recibió peticiones, recorriendo todas las ciudades desde Temuco (en Cautín) hasta Puerto Montt (en Llanquihue), con lo que reunió una

32 Guevara, Costumbres judiciales..., op. cit., 79.

33 Para esta parte, Comisión Parlamentaria de Colonización, Informe, proyectos de ley, actas de sesiones y otros antecedentes, Santiago, Imprenta y Litografía Universo, 1912. 
considerable información sobre el asunto y terminó proponiendo varios proyectos de ley ${ }^{34}$.

Recibió 2.114 solicitudes, algunas colectivas, de las que 1.552 eran de particulares y 563 de indígenas. Los no indígenas pidieron títulos por las tierras que ocupaban y reclamaron contra sociedades de colonización y por abusos de vecinos. Los indígenas otro tanto, y pidieron títulos de merced, solicitaron mayores tierras o el deslinde de las otorgadas, y algunos pidieron la división de sus comunidades.

Entre las autoridades consultadas por la comisión hubo opiniones encontradas. Las hubo muy desfavorables hacia el indígena, proponiendo su rápida integración, y otras más informadas, que destacaron los abusos de que eran objeto y la ineficacia estatal para resolver los problemas.

Entre los primeros, el presidente de la Comisión Radicadora, Leoncio Rivera, señaló el 14 de febrero de 1911, en Temuco, que los despojos que sufrían los indios no se debían a un defecto de la acción estatal, sino que a la inferioridad en que se hallaban los indios. Más tajante fue el médico de colonias, Rodolfo Serrano, que el 11 de marzo de 1911 escribía a la comisión, desde Temuco, que todos los problemas del indígena se originaban por su vida en comunidad. Si se le separaba de su familia, de su raza y su tribu, el indio era inteligente, trabajador y buen soldado. El indio vivía miserablemente y sufría perjuicios por vivir entre indios. Por ello, consideraba que la radicación de los indígenas había sido nefasta, pues se perpetuaban allí los malos hábitos y costumbres, sin beneficio para el país, y se anulaba en el indio toda idea de progreso. Como conclusión, e interpretando a "todos los agricultores y vecinos de la Frontera", proponía que se derogaran todas las leyes de indígenas y que se les tratara como simples colonos nacionales, terminándose al cabo de unos años la prohibición que tenían para vender sus tierras. Con ello, sometidos a la ley común, auguraba que la raza indígena desaparecería:

"no se vería en grupos y en familias, recorrer las ciudades de la Frontera, ostentando sus harapos y miserias, en busca de sus menestras para las más apremiantes necesidades de la vida. Gran parte de sus terrenos habrían pasado a manos de chilenos; esos campos serían cultivados y entregados a las labores de la agricultura moderna. Las pequeñas tribus o aglomeraciones de familias se habrían diseminado [...] y desaparecerían esas reducciones de indios, que no son más que focos de corrupción y borracheras y nidos de rateros, que son la pesadilla de todos los propietarios vecinos" 35 .

Además, las industrias y agricultores tendrían familias indígenas como operarios y estos ganarían mucho más dinero o serían inquilinos de mejores propiedades. En definitiva, serían ciudadanos útiles y trabajadores.

Con más o menos elegancia, las palabras de Serrano reproducían creencias arraigadas en muchos habitantes del sur de Chile. Para ellos, todos los males del indio

34 Hubo un viaje especial de la comisión, en abril de 1911, a Llaima, en la cordillera de la provincia de Cautín, donde había conflictos entre una sociedad colonizadora y los habitantes del lugar (ocupantes y colonos). La empresa había recibido una concesión de 26 mil hectáreas y terminó ocupando 200 mil hectáreas.

35 Comisión Parlamentaria de Colonización, op. cit., 198-200 y 495. 
eran culpa del mismo indio. Su modo de vida era el origen de sus problemas. Ciertamente, era una mirada interesada, pues siempre se podía entrever la atención puesta en las tierras indígenas y en aprovechar su mano de obra, y parcial, pues no reconocía otras razones. También, ella muestra las ideas que tenían muchos chilenos y extranjeros sobre el indio: inferior, decadente, borracho, salvaje, flojo y ladrón, eran algunas expresiones utilizadas para calificarlo. Sin embargo, mágicamente, solo bastaba sacarlo de la comunidad, separarlo de sus pares y ponerlo en contacto con la “civilización" para que surgieran de él todas las virtudes de que antes carecía.

Al contrario, las opiniones más informadas dadas a la comisión contradecían estas afirmaciones y presentaban una versión diferente del asunto. Ellas fueron entregadas por los protectores de indios, funcionarios encargados de la defensa legal y de la representación de los indígenas. Hasta 1906 solo había existido uno para toda la Araucanía, en Temuco, y después se fueron estableciendo otros en las provincias de Valdivia, Llanquihue, Arauco, Biobío y Malleco. Su labor no era eficiente, pues funcionaban con precarias condiciones, sin atribuciones legales claras, ni recursos y atendían territorios demasiado extensos. A pesar de la buena voluntad que ponían, no lograban atender más que una mínima parte de los reclamos que se les hacían. Muchos indígenas los creían asociados a jueces, autoridades locales y particulares para beneficiarse de los abusos que ellos recibían.

Todos ellos denunciaron a la comisión las formas utilizadas para quitar tierras a los indígenas. El protector de Malleco, Manuel Oñate, el 27 de febrero de 1911, señalaba que batallaban contra los "tinterillos":

\begin{abstract}
"que inventan toda clase de argucias y artimañas para complicar y alargar indefinidamente los juicios, y contra usurpadores de terrenos de indígenas, a veces ricos e influyentes, que hacen uso de cuanto medio está a su mano para impedir que se les lance de los terrenos que indebidamente ocupan [...] A medida que sube el valor de la propiedad, aumenta también la codicia de los particulares por apoderarse de los terrenos de indígenas y, por consiguiente, aumenta asimismo la labor de los protectores" 36 .
\end{abstract}

Agregaba, que los particulares contaban con el apoyo de la Justicia:

"si se exhorta a los jueces de menor cuantía, que generalmente son amigos de los usurpadores de las tierras de los indígenas, o dan por perdido el exhorto después de dos o tres meses que lo han tenido en su poder; o dicen que no han podido encontrar a la persona que se quiere notificar, a pesar de que todos los días están juntos"37.

Varios protectores coincidían en que los abusos eran favorecidos por la falta de definición en la ley de quiénes eran indígenas. Así, bastaba negar tal condición para que no pudiera aplicarse la prohibición de vender sus tierras y se impidiera la acción del protector. Los notarios, apoyados en la misma indefinición, seguían aceptando la compraventa de tierras indígenas. De este modo, en todos los juicios 
y reclamaciones los protectores partían siempre por tratar de demostrar que el indígena era tal, pero les era difícil dada la falta de consenso sobre el significado de la expresión "indígena". Había muchos de ellos con apellido español, que hablaban castellano y que vestían de modo similar a los chilenos, a los que era fácil desconocer su carácter de indígenas, aunque lo mismo ocurría con otros cuyo aspecto, lengua, familia y vestimenta eran indígenas.

Dos resquicios legales utilizados para quitar judicialmente tierras a los indígenas eran el juicio por deudas, evitando de ese modo la aplicación de la legislación indígena, ya que las ejecuciones por deudas caían dentro de la ley común; y la compra de acciones y derechos en una comunidad, y después pedir la partición según el derecho común. Esto último especialmente ocurría en la provincia de Valdivia. Después de comprar las acciones y derechos a algunos comuneros, esto es, su parte indivisa dentro de una comunidad, se solicitaba la partición judicial. Como resultado, muchos indígenas quedaban con una cantidad ínfima de tierra o, cuando les tocaba una parte muy pequeña, eran desalojados y compensados en dinero por el valor de la tierra.

Por otro lado, la mayoría de los protectores consideraba que la forma de radicación de los indígenas había sido un error y proponían que se acabara con ella, y se entregaran títulos individuales. Como señalaba el protector de Malleco:

"la comunidad en que viven, es origen de serias dificultades, que surgen entre ellos mismos, degenerando algunas veces en verdaderas batallas; pues sucede que el jefe de la reserva se toma para sí el mejor terreno o la mayor parte de él, y deja a los demás comuneros reducidos a una pequeña extensión. Otras veces ocurre lo contrario: algunos comuneros arriendan la mayor parte de la reserva a particulares, y estos expulsan de los terrenos a los indígenas que no han querido arrendar" 38 .

Por su parte, el protector de Arauco, Manuel Labbé, comentaba, el 8 de abril de 1911:

“como la experiencia aconseja que no es conveniente el régimen de la comunidad o cacicazgo de la propiedad indígena, convendría que, una vez que no hubiere cuestiones de dominio o posesión con particulares ante la justicia ordinaria, en las hijuelas en que existieren reducciones de indígenas radicados, se procediera por el protector, de oficio o a petición de un indígena jefe de familia, a la subdivisión de la hijuela entre las distintas familias de que se componga" 39 .

Hecha la subdivisión, el indígena podría contratar libremente sobre sus terrenos, con la intervención del protector.

En Cautín, para resolver los problemas entre comuneros, el protector había comenzado a dividir las tierras comunitarias; esto no tenía valor legal, pues la ley de 1866 no consideraba más que la petición de recibir propiedades individuales al 
momento de la radicación, pero se asumía como un compromiso entre los comuneros. Desde 1906 tal labor la comenzó a realizar la propia Comisión Radicadora. A este respecto, el protector de Cautín, Eulogio Robles (quien más tarde llegaría a ser ministro de la Corte Suprema), el 15 de abril de 1911, señaló que consideraba mejor la radicación por familias, pero llamaba la atención en la necesidad de fijar un mínimo de hectáreas por persona superior al actual ${ }^{40}$.

Dando una explicación clara de las dificultades crecientes que tenía la vida comunitaria, el protector de Valdivia, Carlos Iribarra, en mayo de 1911, señalaba a la comisión:

\begin{abstract}
"hemos notado que cada día se traen nuevas quejas de indígenas contra indígenas. Son algunos los casos en que un indígena ha venido en juicio y lanzado del terreno a su comunero indígena. Opinamos que estos choques nacen de causas extrañas a sus hábitos, costumbres, etc. Creemos no engañarnos si afirmamos que esas diferencias son de carácter económico"41.
\end{abstract}

Por ello, no eran las desavenencias personales lo que hacía difícil la existencia de la comunidad, sino que la escasez de tierras. Iribarra agregaba:

“es la radicación por familias y la asignación de pequeñas cabidas a reducciones numerosas, una de las principales causas de ese malestar. Así se comprende por qué antes de que actuara la Comisión Radicadora no apareciera este descontento. Está claro. La mencionada comisión los ha reducido en sus posesiones, y, por consiguiente, los ha obligado a acercarse, a conocer y tratarse más íntimamente, lo que los ha hecho darse cuenta más exacta de lo que significa la vida en comunidad. De aquí también el motivo que tienen los indígenas para solicitar que no se les radique y su disposición para renunciar su calidad de tales. Reducidos pues a pequeñas cabidas de terrenos, radicados por familias y con el sistema de comunidad, rompen su tradicional espíritu de cuerpo, unidad y compañerismo para defender su propia conservación, individualmente hablando" 42 .

Para Iribarra, la existencia de la comunidad misma no era el problema, como podía desprenderse de los otros informes; con mayor agudeza, observaba que la razón principal de los conflictos era tener que compartir un terreno insuficiente, que los hacía enfrentarse en una suerte de lucha por sobrevivir. Iribarra era pesimista sobre el futuro, pues los reclamos entre indígenas iban en aumento y preveía que pronto se verían "escenas de hambre".

Por esos años, en 1913, Tomás Guevara, estudioso de los mapuches, recordaba que durante la radicación se habían unido en una misma comunidad familias indígenas emparentadas e indígenas extraños sin tierras. Ello, junto a las dificultades que vivían las comunidades, provocaba una tendencia al debilitamiento de la comunidad. Consideraba que la mayoría de los indígenas estaban interesados en la subdivisión de

\footnotetext{
40 Ibid., 146

41 Ibid., 187

42 Ibid., 188.
} 
sus comunidades, lo que pedían al protector de indios y a la Comisión Radicadora. Incluso llegaban a hacerlo, cuando esas autoridades no les atendían, a través de ingenieros particulares. Señalaba las diversas oportunidades en que los protectores de indios habían informado de las dificultades al interior de las comunidades, como cuando el protector de indios de Cautín, en 1908, comunicaba en su memoria anual:

"en muchas ocasiones, los reclamos de indios contra indios son atendibles, y sería de desear que esta oficina tuviera medios eficaces para resolverlos, pues acontece que algún cacique o mocetón audaz se apodera de las tierras de otro más débil o de alguna viuda, y los deja en la miseria: en ese pequeño mundo de las reducciones también impera la ley del más fuerte" 43 .

El protector de Cautín fue más tajante en su memoria de 1911: "El malestar que se nota en las reducciones tiene como primera causa el régimen de comunidad y no podrá removerse hasta que se subdividan las reservas" 44.

En definitiva, la comisión consideró que había cuatro aspectos que debían resolverse: legislación indígena, colonización nacional, concesiones a empresas particulares y los derechos de ocupantes nacionales. Todos esos temas estaban supeditados al establecimiento de los límites de la propiedad fiscal en sur, especialmente aquella que estaba en manos de ocupantes sin títulos y de propietarios con títulos fraudulentos.

El criterio de la comisión fue elaborar varios proyectos de ley, separando cada tema. Era discutible tal decisión, pues para cualquiera que conociera el asunto era evidente que todos los problemas estaban vinculados, ya que cualquier resolución de los derechos particulares terminaba afectando los intereses de otros particulares e indígenas. Bien pudo, por lo tanto, haberse asumido en conjunto la solución del problema de la tierra. Sin embargo, el criterio de la comisión era el que prevalecía en la práctica, cuando se actuaba sin coordinación en materias de colonización, radicación, remates de tierras y concesiones. Importaba más el fin de poblar la región, hacerla producir, que evitar cometer errores. Menos valía un indígena, un pobre chileno o colono extranjero afectado, que los grandes intereses agrícolas o comerciales.

Respecto a los indígenas, la comisión propuso un proyecto de ley, a partir de otros dos proyectos que estaban en trámite en el Parlamento desde 1905 y 1908. Alejándose de muchas de las opiniones recogidas y de los dos proyectos señalados, creía que no se debía variar el sistema de radicación en aplicación, pues ya se estaba concluyendo; calculaba que en ese momento no faltaban más que unos 8 mil indígenas por radicar. Consideraba que la subdivisión se debía imponer a todas las comunidades pasados treinta años, pero permitiendo que los interesados recibieran títulos de la parte que les correspondiere. Como hasta el momento no había disposiciones para estos casos, el proyecto establecía las reglas que se aplicarían en la división ${ }^{45}$.

43 Citado por Guevara, Las últimas familias..., op. cit., 198-199.

44 Citado por ibid., 200.

45 Comisión Parlamentaria de Colonización, op. cit., XXXII-XLIV. 
Además, mantenía la prohibición de enajenar tierras obtenidas por títulos de merced, impuesta en 1874 y 1893. Sin embargo, aquellos indígenas que tuvieran hijuela propia después de la división, y que supieran leer y escribir, además de estar inscritos en los registros electorales, o hubieran ejercido cargo público, o hecho el servicio militar, o casado en el registro civil, podrían enajenar o hipotecar, en caso de necesidad, previa autorización judicial. El mismo proyecto establecía una definición de indígenas, como aquellos aborígenes que conservaran parte de sus costumbres, idioma o los apellidos de su raza, y que poseyeran terrenos entre Cautín y Llanquihue. La definición no era la mejor, como lo habían advertido los protectores, dejando fuera a indígenas que habitaban en otras zonas y a los que vivían en el sur pero que no tenían tierras.

El proyecto no prosperó, pero vale consignarlo, ya que sus planteamientos fueron considerados al elaborarse las leyes posteriores.

Ninguno de los proyectos presentados por la comisión tuvo éxito. De ellos hay que recordar otro, el que proponía crear un tribunal especial con sede en Valdivia, para resolver sobre todos los juicios que el Fisco hiciera a ocupantes y propietarios fraudulentos de terrenos fiscales al sur del Biobío. La idea venía planteándose por varios años y la comisión la recogió como solución para defender los intereses fiscales. La idea era descabellada e impracticable, pues suponía miles de juicios para el Estado, con lo que el asunto no se resolvería ni en cien años. Ya se perfilaba en el proyecto un intento de sanear, aceptando los hechos consumados, más que de aplicar en estricto rigor las leyes. La comisión no ocultaba los intereses agrícolas que estaban en juego y la necesidad de "legitimar" las propiedades existentes, al plantear: "establecido de esta manera el imperio de la ley en aquellas regiones, vendrán la subdivisión territorial y las enajenaciones; nacerá el crédito y progresará la industria con incremento de la riqueza pública y privada"46.

Un aspecto ausente de las consideraciones del proyecto era que no todas las usurpaciones de tierras eran de particulares contra el Fisco. Fuera del interés estatal quedaban los perjuicios provocados a particulares e indígenas. A eso se respondía, que los afectados tendrían que defender sus derechos en los tribunales. Pero esa no era una vía accesible para la mayoría. Además, era obvio que una vez que el Estado sancionara los títulos de particulares, estos tendrían valor universal, no solo respecto al Estado.

A pesar de los graves problemas existentes, nada resultó en lo inmediato de todo lo obrado por la comisión.

Más adelante, en 1915, la comisión de Colonización de la Cámara de Diputados presentó un nuevo proyecto sobre indígenas, para la radicación por familias de los que aún no recibían un título de merced, que permitía, con ciertas condiciones, que el indígena pudiera disponer libremente de sus tierras ${ }^{47}$. Se proponía el término del trato especial que la ley daba a los indígenas y sus propiedades. En la presentación del proyecto se daban argumentos a favor de tal decisión:

46 Ibid., LXIV.

47 José Luis Ureta, La constitución de la propiedad austral, Santiago, Imprenta Universidad, 1927, 66-67 y 94-96. 


\begin{abstract}
"la raza indígena ha alcanzado ya un grado de progreso que no difiere sensiblemente del común de nuestro pueblo y no parece justo establecer para ella una legislación especial que la prive de los derechos que nuestras leyes comunes conceden a todos los ciudadanos del país, o que les otorgue exenciones que no guardan conformidad con el estado actual de nuestra civilización [...] [lo que] ha impedido a los indígenas asimilarse a nuestra raza y los ha mantenido independientes de nuestra civilización, formando un pueblo aparte de nuestro pueblo. En las partes del territorio en que no han regido estas exenciones, los indígenas han sido rápidamente absorbidos por la raza nacional; ellas no están justificadas ni aún por la defensa o amparo de los indígenas, pues estos son los primeros que protestan de esta extraña protección, que les impide ejercer los derechos de ley común que faculta a cada cual para disponer de lo que le pertenece" 48 .
\end{abstract}

Detrás del proyecto estaba la idea de favorecer la propiedad privada y el progreso asociado al espíritu capitalista y a los agricultores "modernos". Estaba la relación hecha entre término de la radicación y permitirles a los indígenas comerciar sus tierras con la plena integración, así como quedaba implícito el interés existente en los chilenos por apropiarse de esas tierras.

\title{
LEGISLACIÓN SOBRE LAS TIERRAS DEL SUR EN LOS AÑOS VEINTE
}

Como hemos dicho, los propietarios rurales del sur estaban desprestigiados y, en el resto del país, muchos creían que la mayor parte de ellos había obtenido sus tierras vulnerando los derechos del Estado, indígenas y campesinos pobres. Por ello, en los años veinte se buscó una solución, considerando la constitución de la propiedad austral, como se llamaba a la solución de la precariedad de los títulos de propiedad rural y la división de comunidades indígenas. Sin embargo, el tratamiento que se les dio no fue el mismo; mientras hubo un interés permanente y prioritario por resolver los problemas de los agricultores no indígenas, los asuntos de estos últimos fueron poco relevantes. Claramente, los intereses de los segundos se supeditaron a los de los primeros.

La convicción del centro del país sobre la ilegalidad de la propiedad de los agricultores sureños se expresó en una decisión de la Caja de Crédito Hipotecario en 1920, que de una entrega de créditos discriminatoria a los propietarios australes, pasó a negarlo mediante un requisito insuperable para la mayoría, como fue que sus títulos procedieran del Fisco o que fueran anteriores a 1866, debidamente inscritos y registrados. Como reacción a ello se realizó un Congreso Pro Defensa de la Propiedad Austral, en Valdivia, en abril de 1921, al que concurrió el ministro del Interior, congresales y representantes de las provincias del sur. Dentro de los resultados de dicho encuentro, se pidió al Gobierno tomar diversas iniciativas legales para resolver la situación de propietarios y ocupantes de terrenos en el sur ${ }^{49}$.

$48 \quad$ Ibid., 66

49 Luis Morales Zuaznábar, La legislación indígena ante nuestros poderes públicos, Santiago, Imprenta Bellavista, 1923, 28-29; y Ureta, op. cit., 119-120. 
Como hemos visto, la comisión parlamentaria que recorrió desde Temuco hasta Puerto Montt, propuso varios proyectos de ley; de ellos nos interesa destacar aquí la suerte que corrió el que se refería a la constitución de la propiedad en el sur y a la creación de un tribunal especial.

El proyecto tuvo un largo trámite y recién en julio de 1922 pasó al Senado. Se proponía que un tribunal con sede en Valdivia resolviera todas las contiendas por tierras entre particulares y el Estado, al sur del río Malleco, en un plazo de cinco años. El tribunal debería considerar preferentemente dentro de las partes a aquella que tuviera la posesión material del terreno, y a la que hubiera invertido capitales y trabajado el suelo. Los procesos comenzarían en los juzgados de letras y pasarían antes de la sentencia a la Corte de Apelaciones de Valdivia, donde radicaría el tribunal señalado, para su resolución definitiva. Las sentencias del tribunal serían de única instancia. Por otro lado, se autorizaba que el Fisco pudiera transar una causa, con aprobación final del tribunal, lo que extinguiría el juicio existente.

Lo propuesto por el proyecto de ley reseñado jugaba a favor de los particulares, por varias razones. Primero, en ningún caso el Fisco podría defender todos sus derechos en plazos tan breves; segundo, los particulares poseedores o mejoreros serían privilegiados, sancionando las ocupaciones y usurpaciones; tercero, los juicios abrían la posibilidad de que con buenos abogados se pudieran fabricar todo tipo de pruebas, alargando las causas y forzando las transacciones. Claramente, el proyecto favorecía el pragmatismo, los hechos consumados, por sobre el imperio de principios jurídicos tradicionales. Con algunas diferencias, el proyecto señalado se transformaría en ley en octubre de 1925, con lo que el anhelo de los propietarios de tierras tuvo por fin una respuesta gubernamental ${ }^{50}$.

Por ese momento, la ilegitimidad de sus títulos los tenía sin acceso a créditos hipotecarios y les impedía transar sus tierras libremente; nadie quería prestar dinero ni comprar tierras a quienes eran calificados como usurpadores. Para los agricultores, todo ello era una campaña de infundios y el Estado debía resolver el asunto prontamente, ya que de otro modo la agricultura sureña no podría progresar.

La ley señalada surgió bajo la presión de los sureños. El 14 y 15 de junio de 1925 se había llevado a cabo una importante reunión de agricultores del sur de Chile en la ciudad de Valdivia, con el fin de crear un movimiento para defender los intereses agrarios. Fruto de esa reunión se dio a conocer un manifiesto, cuyo fin era dar origen a un partido agrario. En él se hacían referencias a cuestiones generales, tales como el robustecimiento del principio de autoridad, respeto al derecho de propiedad, protección a la producción nacional, especialmente a la agricultura, etc..$^{51}$.

Aunque no hubo una referencia en dicho documento, en la reunión se trató de la necesidad de solicitar la pronta creación del tribunal señalado. Se creía que este podría resolver el ambiente de temor existente entre los propietarios, que a pesar de

50 La Aurora, 26 y 30 de junio, 18 y 23 de julio, 9, 16, 23 al 25 y 29 de agosto, 3 al 7, 12 y 19 de septiembre, 4, 6 y 23 de octubre, 5 y 24 de noviembre de 1925.

51 Idem, 23 de julio de 1925. 
trabajar sus campos por varias décadas no tenían claro el futuro. Además, se trató la falta de préstamos por parte de la Caja Hipotecaria, Caja de Ahorros y bancos ${ }^{52}$.

La reunión de agricultores tuvo muy buena acogida en la Sociedad Nacional de Agricultura (SNA) ${ }^{53}$. Ella coincidía con el rol político más activo que estaba asumiendo y proponía esta organización.

Luis Urrutia Ibáñez, por estos años diputado por Valdivia y partidario de la creación de un partido agrario, escribía en La Aurora, en julio de 1925, que si los problemas de los agricultores no habían tenido solución hasta la fecha era por la falta de alguien que defendiera sus intereses en la capital ${ }^{54}$.

Hacia agosto de 1925 se sabía que el Presidente de la República dictaría un decreto ley sobre la constitución definitiva de la propiedad austral. La Aurora señalaba: "cuando sea una realidad este decreto ley, ya no habrá desazones ni descalabros para los agricultores del sur; la garantía de sus propiedades será suficiente para conseguir préstamos a los bancos y a la Caja Hipotecaria, y así se hará rendir al máximo a todas las propiedades" ${ }^{55}$. Para este diario, el asunto era un problema de "falta de orden" o meramente "administrativo", de rápida resolución, sin entrar para nada en sus orígenes.

Sobre la ley por venir, llegaron noticias al sur de que se harían cambios al proyecto conocido desde hace tiempo, que ya hemos comentado, como darle a la Corte de Apelaciones de Temuco la competencia en estos temas y no crear un tribunal especial en Valdivia. Había malestar en el sur por la nula participación de las provincias afectadas en la preparación de la nueva ley ${ }^{56}$.

El 16 de agosto de 1925 nació en Valdivia la Asociación de Agricultores, a petición de la SNA, resultado de los esfuerzos de esta por establecer filiales en todo el país. Uno de los primeros acuerdos de la asociación fue pedir al Gobierno que creara en Valdivia el tribunal que constituiría la propiedad de la tierra en el sur de Chile.

Por septiembre de 1925, estando a punto de salir la tan esperada ley, se rumoreaba que la mayoría de los ministros de Alessandri eran de la idea de que el tribunal se estableciera en Santiago, así como de revisar todos los títulos posteriores a las leyes de 1866 y 1874. Para evitar ello, desde Valdivia se comunicó con el Gobierno la Asociación de Agricultores y la Cámara de Comercio. Esta información fue desmentida por el Presidente y funcionarios de Gobierno ${ }^{57}$.

Por mediados de septiembre, localidades como Pitrufquén, Gorbea, Loncoche, Valdivia, San José, Río Bueno, La Unión y Puerto Varas, de las provincias de Cautín, Valdivia y Llanquihue, enviaron delegados a Santiago para pedir al Gobierno que se dictara la ley sobre constitución de la propiedad austral ${ }^{58}$.

\footnotetext{
52 Idem, 26 de junio de 1925.

53 Idem, 30 de junio de 1925.

54 Idem, 18 de julio de 1925.

55 Idem, 9 de agosto de 1925.

56 Idem, 16 de agosto de 1925 .

57 Idem, 3 al 7 de septiembre de 1925 .

58 Idem, 12 de septiembre de 1925.
} 
Luis Urrutia Ibáñez, experto en el asunto, escribía en el diario La Aurora por esos días, recordando la gravedad del tema que estaba por resolverse; señalaba que en 1918 la Corte Suprema había declarado que la ley de 1893 suspendió la prescripción como modo de adquirir en las provincias de Valdivia, Llanquihue y Chiloé, estableciendo que los contratos posteriores a 1866-1874 exigían título inscrito y registrado para la compraventa y otras exigencias si el vendedor era indígena. Creía que en Valdivia, La Unión y Osorno, solo uno entre cien de los títulos cumplía con esas disposiciones. De ese modo, reconocía que el fiscal de la Caja de Crédito Hipotecario había tenido razón, en 1920, para establecer que los títulos de dominio de las provincias australes válidos eran los que procedían del Fisco con posterioridad a 1866 y los anteriores que estuvieran inscritos y registrados. Como resultado de tal posición oficial, no hubo créditos hipotecarios de largo plazo puestos en la zona, a pesar de que el avalúo fiscal del territorio era de unos 500 millones de pesos. Además, los terrenos estaban depreciados por el desinterés de los inversionistas del centro del país. Sin embargo, consideraba injusto todo lo anterior, pues los verdaderos dueños eran quienes habían trabajado en la región, a veces por varias décadas. Urrutia señalaba que sería interminable para el Fisco iniciar miles de juicios, más si en el caso de ganarlos debía pagarles a los ocupantes los capitales invertidos en los terrenos. La fantasía política que se perseguía era descrita así: "nadie ignora que el fisco es el demandante menos feliz, pues carece de amistades e influencias necesarias para buscar y encontrar testigos y es defendido por abogados a sueldo, con escasa renta y en este caso, lucharía solo, en contra de los habitantes de tres provincias" 59 .

A aquellos que creían, por ignorancia, que los propietarios rurales del sur tomaron fraudulentamente sus bienes del Fisco o de los indígenas, Urrutia les recordaba que muchos propietarios australes tenían derechos coloniales, tan legítimos como los de los habitantes del centro del país. Creía que si hubo abusos, fueron pocos, y si no hubo cuidado en las transacciones, fue por el escaso valor que la tierra tuvo años atrás. Por lo demás, el gran responsable de los errores y engaños fue la desidia de las autoridades, que participaron o no impidieron que los abusos y defectos ocurrieran. Finalmente, consideraba que los proyectos de ley debatidos no resolvían el problema, pues ponían en un mismo saco toda la propiedad rural austral, pudiendo haberse reducido a aquellas tierras que se compraron a indígenas con posterioridad a $1893 \mathrm{y}$ a las que no se tomaron del Fisco y no hubieran prescrito.

El 18 de septiembre de 1925 fue recibida una delegación de cincuenta agricultores del sur en La Moneda, acordando con el Presidente que una comisión de tres personas del sur (Luis Urrutia Ibáñez, Enrique Hevia y Arturo Montesinos) participaría en el proceso de generación de la nueva ley. Los delegados entregaron al Presidente un memorial, pidiéndole corrigiera el error de interpretación de la legislación que estaba poniendo en debilidad a los propietarios y que dictara pronto la ley que constituyera la propiedad rural austral. En una parte de tal documento se señalaba:

\footnotetext{
59 Idem.
} 
"que no se moleste a los propietarios y poseedores legítimos; que no se les confunda con usurpadores de suelos fiscales o de indígenas, como por lamentable error se ha hecho recientemente en resoluciones judiciales [...] Desconocer el derecho del propietario o del legítimo poseedor, importa incitar a inquilinos y arrendatarios a que se arroguen derechos que no le corresponden" $" 60$.

A comienzos de octubre de 1925, tras la renuncia de Alessandri, quedó Luis Barros Borgoño como vicepresidente de la República. Luis Correa Vergara, consejero de la SNA, pasó al Ministerio de Agricultura, Industria y Colonización, lo que favoreció la comunicación de los intereses de los agricultores sureños al Gobierno. Dicho sea de paso, este último había estado en Valdivia en el congreso de junio ${ }^{61}$. A un telegrama de los agricultores valdivianos, felicitándolo y pidiéndole apurar la ley anhelada, Correa respondió que se hallaba convencido de tal necesidad y que trabajaría por ello ${ }^{62}$.

El 14 de octubre de 1925 se dictó la ley que establecía un procedimiento para la constitución de la propiedad austral ${ }^{63}$. Ella dispuso que cualquier particular que no tuviera títulos dados por el Estado, o surgidos de compras a indígenas antes de las leyes de prohibición (1874 para la Araucanía y 1893 de Valdivia al sur), o de una sentencia definitiva en un juicio seguido contra el Fisco, estaba obligado a demandar al Estado ante las cortes de apelaciones de Temuco o Valdivia, según la ubicación de la propiedad, antes de dos años, de lo contrario perdería sus derechos sobre esas tierras. Además, los que tuvieran títulos inscritos con anterioridad a 1893, de Valdivia al sur, debían registrarlos en una oficina estatal. El Estado tendría dos años para impugnar estos y pasado este tiempo quedarían saneados. Por último, se permitía a los ocupantes de tierras fiscales solicitar un título o, si demostraban una ocupación de más de 10 años, poder comprar hasta 3 mil hectáreas de tierras.

Claramente, el propósito de la ley era establecer los derechos de los particulares respecto al Estado, sin resolver los conflictos existentes entre particulares y con indígenas. Así, aquellos que lograran sostener sus derechos ante el Estado quedarían en mejor pie para defenderse frente a otros. A pesar de que los indígenas fueron excluidos de estas obligaciones, su aplicación los afectaba, ya que el agricultor reconocido como propietario por el Estado obtenía un argumento decisivo para detener cualquier reclamo indígena en su contra.

Como se aprecia, todas las propiedades adquiridas por negocios entre particulares quedaban sometidas a juicio o a revisión. Si consideramos que, a lo menos de Valdivia al sur, el principal modo de adquirir tierras había sido entre particulares, el problema era de una envergadura considerable. Según datos de 1917, los fundos de la provincia de Valdivia abarcaban 1.555.600 hectáreas, de las cuales solo 352.533 habían sido enajenadas por el Estado. En la provincia de Llanquihue el asunto era más serio, pues de 1.457.300 hectáreas que abarcaban los

\footnotetext{
60 Idem, 19 de septiembre de 1925.

61 Idem, 4 octubre de 1925.

62 Idem, 6 de octubre de 1925.

63 Instituto Nacional de Asuntos Indígenas, op. cit., 39-47.
} 
fundos, solo 89.066 derivaban del Estado. Las diferencias procedían de transacciones entre particulares, principalmente por participación de indígenas o apropiación de terrenos baldíos ${ }^{64}$.

A pesar de las esperanzas puestas en esta ley por sus promotores, su aplicación fue escasa. El contexto político no fue el adecuado y los procedimientos definidos (juicios, anotaciones de títulos y solicitudes) eran lentos y engorrosos.

Quizás lo más débil de la legislación creada era que no contemplaba la posibilidad de enfrentar los problemas entre particulares, que eran la principal fuente de irregularidades. A pesar de lo que se creyera, en el sur de Chile hubo antiguos propietarios con títulos, incluso anteriores a la existencia del Estado chileno, como en el caso de Valdivia y la isla de Chiloé, realidad que la ley desconocía, suponiendo que la fuente principal de propiedad era el Estado. Como no se contemplaba un medio para resolver conflictos de particulares e indígenas, fuera de los trámites judiciales ordinarios, los perjudicados terminaron sin una solución real.

Urrutia Ibáñez, consultado por el diario La Aurora, señaló que el decreto-ley era favorable, ya que dejaba fuera de revisión las propiedades urbanas y permitía a los ocupantes de terrenos fiscales ser dueños, siempre que tuvieran una ocupación de más de 10 años. Respecto a la explotación de un terreno, como prueba, había muchas formas de ella, por lo que era fácil establecerla. Un aspecto que consideraba perjudicial a los intereses fiscales era que los jueces no debían apreciar en conciencia los testimonios, solo aceptar los dados, pues era más fácil a los particulares llevar testigos que al Fisco. Aunque echaba de menos una referencia explícita a que las leyes anteriores a 1893, sobre transacciones de tierras, no se aplicaron de Valdivia al sur; pensaba que con haber favorecido la prescripción después de 10 años se entendía que los más antiguos propietarios lo eran con mayor derecho. De esta entrevista quedaba claro que fue por presión de él, Hevia y Montecinos, que el Gobierno cambió su parecer de obligar a los propietarios rurales del sur a demandar, por solo anotar sus títulos. Asimismo, se pudo aplicar la prescripción a propiedades mayores a mil hectáreas y exceptuar las propiedades urbanas. Había confianza en Urrutia, pues pensaba que ningún funcionario sería tan insensato como para que, después de exhibidos los títulos de dominio, desposeyera a los dueños de sus propiedades pretendiendo que en la zona regían las leyes de 1866, 1874 y $1893^{65}$.

Hacia noviembre de 1925, al calor de las elecciones parlamentarias, el candidato a diputado por el recién formado Partido Agrario (distinto al que surgiría más tarde en Temuco), don Alfredo Agüero Vío, planteaba entre otras promesas electorales la de exigir al Gobierno que se aplicara el decreto ley de constitución de la propiedad en forma justa y ecuánime, sin molestar a ningún propietario legítimo. Además, proclamaba: "solamente deseo que el último inquilino y el pequeño y grande propietario rural sepan que yo representaré en la Cámara sus intereses y seré el vigilante guardián de sus derechos"66.

64 Torrealba, Tierras fiscales y de indígenas..., op . cit., 23-28.

65 La Aurora, 23 de octubre de 1925.

66 Idem, 5 de noviembre de 1925. 
En la oportunidad, fue elegido senador por Valdivia José Maza, quien fuera el ministro de Justicia de Alessandri, que junto al ministro de Agricultura y al comité valdiviano redactaron el decreto ley ya comentado. Maza tuvo un papel determinante en el texto final, especialmente cuando se discutió sobre si las leyes de 1866 y 1874 habían regido antes de 1893 desde Valdivia al sur. Maza fue de la idea de que en Valdivia, Llanquihue y Chiloé habían regido las leyes comunes antes de $1893^{67}$.

En julio de 1926 se presentaron dos proyectos de ley ante la Cámara de Diputados, para hacer correcciones a la ley anterior, ampliando en un año los plazos fijados y excluyendo a los pequeños propietarios de los trámites para la constitución de la propiedad austral, con lo que se inició una serie de reformas legales, que mantendrían en el debate nacional este tema por los próximos cinco años ${ }^{68}$.

En el mismo año también se elaboró un proyecto sobre las comunidades indígenas. La coincidencia no es casual, pues en ambos casos se buscaba resolver "anomalías" sobre la propiedad de la tierra; la precariedad de los títulos y la existencia de la propiedad comunitaria indígena, se creía, afectaban el progreso del sur.

El 4 de agosto de 1926 el presidente Emiliano Figueroa envió a la Cámara de Diputados un proyecto de ley para dividir las comunidades indígenas ${ }^{69}$. Se proponía poner fin al régimen legal de excepción en que estaban los indígenas, por ser el origen del "problema indígena". Las leyes del siglo XIX, que prohibieron a estos celebrar cualquier contrato sobre sus tierras, ya no eran necesarias. Muchos indígenas estaban civilizados; sabían leer y escribir, habían hecho el servicio militar y ejercían cargos públicos y profesiones liberales. Era absurdo seguir prohibiendo a estos individuos que realizaran contratos y negocios con su patrimonio.

A pesar de lo que dijera el Gobierno, la realidad era diferente; la mayoría permanecía al margen de la educación formal y solo un pequeño grupo estaba "civilizado". El argumento era débil, pues chocaba con una verdad contraria evidente, pero era el adecuado para señalar el "anacronismo" de la legislación.

Además, en el mensaje presidencial se decía que el mantenimiento de tales prohibiciones a los indígenas y la propiedad comunitaria afectaba la economía del sur:

“de aquí proviene la estagnación y la pobreza de esa zona que puede ser una de las más prósperas y ricas del país. Los indígenas en tales condiciones, incapaces de celebrar contratos, quedan de hecho incapacitados para concurrir en igualdad de condiciones, con el resto de los ciudadanos chilenos en las fecundas actividades del progreso y del trabajo. No pueden introducir adelantos, adquirir maquinarias, abonar sus terrenos, etc., porque los indios no derivan de sus suelos otra ventaja positiva que la simple posesión, no pueden darlos en garantía hipotecaria, ni siquiera en arrendamiento, porque, como se ha dicho, todas esas naturales y legítimas actividades les están prohibidas por obra de las mismas leyes que se dictaron con la mira de beneficiarlos"70.

67 Idem, 24 de noviembre de 1925.

68 Cámara de Diputados, Boletín de Sesiones, 1926, 1.260-1.261, 1.319-1.321, 1.411-1.413 y 1.547-1.550.

69 Ibid., 1.950-1.952.

$70 \quad$ Ibid., 1.950. 
Para el Gobierno, más importante que las malas y escasas tierras que habitaban la mayoría de los indígenas, que los abusos que los afectaban, era la propiedad comunitaria y la legislación prohibitiva lo que impedía su progreso y el de la región. Eliminados estos obstáculos, los indígenas mejorarían su situación.

Así, se proponía que agrimensores del Estado procedieran a la división de las comunidades, dándole a cada jefe de familia o indígena radicado una parte de la reducción. En ese trabajo colaborarían los protectores de indígenas y la Comisión Radicadora de Indígenas. Ningún indígena recibiría tierras en más de una comunidad, perdiendo sus derechos hereditarios en otras reducciones. Los jefes de familia que no quedaran satisfechos con la hijuela que se les adjudicara, podrían pedir que se les ubicara como colonos en terrenos fiscales, siendo repartido el terreno que les correspondía entre los demás comuneros. También se repartiría entre los comuneros la parte de los indígenas ausentes. Además, serían consideradas válidas las divisiones de hecho realizadas hasta ese momento. Terminada la división e inscritas las hijuelas en el conservador de bienes raíces, quedarían sometidas a las leyes comunes las propiedades de aquellos indígenas que tuvieran alguno de los siguientes requisitos: los que fueran ciudadanos (varones que sabían leer y escribir y mayores de 21 años) y estuvieran casados por las leyes comunes; los que hubieran cursado la educación primaria, estuvieran casados por las leyes comunes con mujer que supiera leer y escribir, y los que tuvieran hijos que supieran leer y escribir. Los indígenas considerados en los dos últimos casos deberían solicitar autorización judicial para disponer de sus bienes. En general, todos los indígenas después de cinco años de hecha la partición de la comunidad podrían disponer libremente de sus tierras, solamente solicitando autorización judicial. Por último, las disposiciones de esta ley regirían en todo el sur de Chile, a partir de la provincia de Biobío.

Como el mismo Presidente de la República señalaba, el proyecto de ley era el fruto de diversas reuniones realizadas con funcionarios encargados de esa materia, con indígenas y parlamentarios del sur de Chile. El diputado mapuche Manuel Manquilef fue uno de los que más contribuyó a la idea central del proyecto, convencido de la necesidad de dividir las comunidades ${ }^{71}$. Sin embargo, su creencia no era compartida por todas las organizaciones mapuches del sur. La Sociedad Caupolicán y la Federación Araucana se opusieron rápidamente al proyecto, mientras la Unión Araucana le dio su apoyo ${ }^{72}$. En todo caso, las organizaciones mapuches consideraron que la nueva ley debía incluir otros aspectos, como la radicación de los indígenas que aún no recibían títulos de propiedad y la restitución de las tierras usurpadas a las comunidades.

71 Años antes, Manquilef ya había elaborado un proyecto de división de las comunidades, que incluyó en su libro ;Tierras de Arauco! El último cacique, publicado en Temuco, en 1915. Según este, la comunidad era el origen de todos los males del indio. Augusto Samaniego y Carlos Ruiz Rodríguez, Mentalidades y políticas wingka: pueblo mapuche, entre golpe y golpe (de Ibáñez a Pinochet), Madrid, CSIC, 2007, 162-169.

72 Ver Rolf Foerster y Sonia Montecino, Organizaciones, líderes y contiendas mapuches (19001970), Santiago, CEM, 1988, para mayor información sobre estas organizaciones mapuches. 
Considerado el proyecto de ley por la comisión de Agricultura y Colonización de la Cámara de Diputados, fue aceptado en lo esencial, pero corregido en cuanto al procedimiento a seguir para dividir las comunidades ${ }^{73}$. La comisión, según informe de septiembre de 1926, aceptaba que las leyes sobre indígenas no eran adecuadas, pues estos tenían una cultura e instrucción muy similar al resto de los habitantes del sur de Chile. También, enfatizaba los beneficios económicos que:

"reportaría a esas ricas provincias la incorporación a las leyes comunes de los territorios y riquezas que poseen los araucanos, y la facultad que se les concede, bien es cierto con limitaciones, de comerciar y ejercer los demás derechos civiles otorgados a los demás habitantes del país, no cabe la menor duda de la conveniencia que representa para los intereses generales la aprobación del proyecto en informe" 74 .

Además, se planteaba que en las comunidades vivía un número considerable de allegados indígenas, que no tenían derecho a esas tierras y perjudicaban a sus legítimos dueños, herederos de los que recibieron el título de merced.

A diferencia del proyecto del Gobierno, la comisión propuso que la división fuese hecha por un tribunal especial, compuesto por el presidente de la Comisión Radicadora, por un protector de indígenas y por un agrimensor. Este tribunal resolvería todos los problemas relacionados con la división de la comunidad y sus fallos serían inapelables. Por otro lado, aunque aceptaba que ningún indígena recibiera tierras en más de una comunidad, como estaba en la propuesta del Gobierno, proponía respetar sus derechos hereditarios en otras comunidades. En lo demás, la comisión apoyó el proyecto gubernamental.

Iniciada la tramitación del proyecto, algunos dirigentes mapuches enviaron comunicaciones, se reunieron para discutir el asunto y viajaron a Santiago para plantear al Gobierno y al Parlamento sus reparos. Por ejemplo, en diciembre de 1926, la Federación Araucana invitó a uno de sus congresos anuales a los senadores Artemio Gutiérrez y Luis Concha y a los diputados Héctor Álvarez y Nicasio Retamales. Por intermedio de estos parlamentarios y por comunicación directa de los resultados del congreso al Gobierno, la Federación Araucana hizo conocer su posición ante las autoridades; entre otros aspectos, reclamaban por la usurpación de sus tierras por particulares y pedían la restitución inmediata de esas tierras por vía administrativa, sin necesidad de iniciar juicio, ya que la ley vigente prohibía a los particulares poseer esos terrenos ${ }^{75}$. Aunque la idea esencial del proyecto, la división de las comunidades, no fue modificada por el Parlamento, tales manifestaciones produjeron algunos importantes cambios ${ }^{76}$.

En definitiva, tanto la Sociedad Caupolicán como la Federación Araucana se encargaron de indisponer a los mapuches contra la división de las comunidades, mientras la Unión Araucana la apoyaba abiertamente y atacaba a los dirigentes de

\footnotetext{
73 Cámara de Diputados, Boletín de Sesiones, 1926, op. cit., 3.066-3.069.

74 Ibid., 3.066.

75 Senado, Boletín de Sesiones, 1927, 2.108-2.109.

76 Foerster y Montecino, op. cit., 23-26, 40-46, 54-60 y 73-78.
} 
las otras organizaciones que la criticaban. En esta polémica el más activo opositor de la división de las comunidades fue Manuel Aburto Panguilef, que terminó siendo relegado por el Gobierno, a petición del prefecto apostólico de los capuchinos, Guido Beck, en noviembre de 1927.

En la discusión parlamentaria hubo voces disidentes. En febrero de 1927 el diputado comunista Carlos Contreras Labarca se opuso al término de las comunidades, pues ellas no serían reemplazadas por un sistema superior, sino que se dejaba a los indígenas sometidos a la lógica individualista ${ }^{77}$. En mayo de 1927 varios diputados manifestaron dudas sobre si era conveniente acabar tan drásticamente con las prohibiciones que tenían los indígenas para disponer de sus tierras, ya que se corría el peligro de que las perdieran rápidamente ${ }^{78}$. Para Manquilef, promotor principal del proyecto, ello era posible de corregir pero siempre que se apoyara la división de las comunidades. Con ese acuerdo fundamental prosperó el proyecto. En todo caso, el diputado Abraham Quevedo señaló dudar de los beneficios de acabar con las comunidades, considerando las pequeñas propiedades con las que quedaría cada familia indígena. Manquilef planteó que la comunidad indígena era un invento de los ingenieros que radicaron a los indígenas, reuniendo en una misma reducción a indígenas que no tenían ningún parentesco entre sí. Estaba de acuerdo con extender el plazo para que los indígenas incultos pudieran disponer de sus bienes, pues con la sola división de la comunidad el indígena mejoraría su condición, al hacerse propietario individual. Por su parte, el diputado Héctor Álvarez agregó que la comunidad no correspondía a las tradiciones mapuches y que estaba demostrada la ineficacia de las comunidades. Sin embargo, dio a conocer las demandas que los indígenas habían expresado en el congreso organizado por la Federación Araucana: que la venta de tierras fuera una facultad excepcional para los indígenas; que en la división de comunidades cada familia recibiera tantas tierras como las que se daban a los colonos chilenos y no solo las que obtendrían por la mera partición de las tierras comunitarias; que se entregaran tierras de cabida diferente según el lugar, debiendo darse más en terrenos montañosos; y que se prosiguiera con la radicación de los indígenas de Valdivia al sur, los que en su mayoría no tenían títulos sobre las tierras que ocupaban. Tales solicitudes fueron planteadas por Álvarez como un contraproyecto de ley, que la Cámara desechó por amplia mayoría, aunque por la vía de la indicación se hicieron correcciones en el mismo sentido al proyecto en discusión.

Por otro lado, el diputado Luis Urrutia Ibáñez destacó los beneficios económicos que generaría el término de las comunidades, argumento recurrente para vencer las discrepancias que generaba el proyecto. Urrutia, abogado en Valdivia y destacado defensor de los derechos de los terratenientes del sur de Chile en el Parlamento, creía que muchos males de la agricultura regional se debían a la existencia de las comunidades. Para él, la propiedad privada de la tierra era la única forma que aseguraba verdadero progreso. Así, cada cual tiene lo suyo y lo

77 Samaniego y Ruiz Rodríguez, op. cit., 151-161.

78 Cámara de Diputados, Boletín de Sesiones, 1927, 106-114. 
defiende. Aceptaba que era peligroso que los indígenas pudieran repentinamente disponer libremente de sus tierras, pues podrían venderlas con "ánimo ligero" y quedar sin su fuente de ingresos. Sugería que en vez de vender se les permitiera permutar sus tierras, con lo que se lograría un doble beneficio; seguirían siendo propietarios, pero a la vez se podría integrar efectivamente a la economía las tierras que ocupaban actualmente los indígenas. Para justificar ello, Urrutia describía un cuadro de abandono generalizado de las tierras indígenas, muchas ubicadas en las cercanías de las ciudades. Los mejores terrenos, sentenciaba el diputado, no podían estar en manos de los indígenas, que no sabían ni podían aprovecharlos. La idea no tuvo respaldo, ya que la permuta siempre sería perjudicial para el indígena, pues las tierras que recibiría, aunque más extensas, serían de menor calidad y estarían lejos de los centros urbanos. El diputado Quevedo desmintió que las tierras mapuches estuvieran abandonadas, encontrándose muchas de ellas en mejor condición que las de los chilenos. Además, señaló que había que mantener a los indígenas cerca de los chilenos para que se civilizaran, lo que no se lograría enviándolos a las montañas ${ }^{79}$.

Finalmente, el proyecto fue aprobado por la Cámara, con pequeñas correcciones. Entre otras, se facultó al tribunal especial para conocer de forma sumaria e inapelable sobre los juicios de demarcación y cercamiento de terrenos indígenas. La moción fue propuesta por el diputado Urrutia, con el objetivo de obligar a que los indígenas cercaran las hijuelas que se les entregaran y se acabara físicamente con la existencia de tierras colectivas sin cercos. Sin embargo, la indicación fue considerada por Manquilef como un buen medio para que los indígenas pudieran recuperar las tierras que les habían usurpado chilenos y extranjeros. Así mismo lo entendieron otros diputados y la proposición fue aceptada. Además, se incorporó en el tribunal especial, fuera de los funcionarios mencionados, a un representante de los indígenas ${ }^{80}$. Por su parte, el Senado hizo algunas correcciones al proyecto. Entre las que fueron aceptadas por la Cámara de Diputados: que el tribunal estuviera compuesto por un ministro de la Corte de Apelaciones de Temuco, por un indígena y por un agrimensor; darle preferencia en la división a las comunidades que lo solicitaran; respetar, en lo posible, a los poseedores de tierras en las comunidades, frente a los mencionados en el título de merced; el tribunal especial conocería de los juicios entre indígenas y particulares y los resolvería de forma sumaria; y, si la unanimidad de la comunidad lo deseaba, podría permutar sus tierras, debiendo el tribunal asegurarse que tal medida beneficiara a los indígenas.

El 29 de agosto de 1927 fue promulgada la Ley de División de Comunidades Indígenas ${ }^{81}$. Por ella se creó un tribunal especial, con asiento en Temuco, que procedería a tal tarea, compuesto por un ministro de la Corte de Apelaciones de Temuco, por un indígena y un agrimensor de la Dirección General de Tierras, Bosques y Pesca. Todos serían nombrados por el Presidente de la República. El tribunal trami-

\footnotetext{
$79 \quad$ Ibid., 178-193.

$80 \quad$ Ibid., $1.743-1.748$ y 2.014-2.018.

81 Instituto Nacional de Asuntos Indígenas, op. cit., 48-51.
} 
taría y fallaría todo lo relacionado con la división de las comunidades y sus fallos serían inapelables. La comunidad se dividiría en tantas hijuelas como jefes de familias, sucesiones o individuos aparecieran en el título original ${ }^{82}$. Los indígenas que no quedasen conforme con su parte podrían ser radicados como colonos, pasando su cuota en la comunidad a los demás comuneros. Estas hijuelas serían preferidas para la fundación de escuelas. El tribunal debería restituir a cada comunidad las tierras que originalmente estaban asignadas por el título de merced. Hecha la división, las hijuelas resultantes serían inscritas en el conservador de bienes raíces respectivo. Posteriormente, aquellos indígenas que hubieran cumplido con la Ley de Instrucción Primaria Obligatoria, o tuvieran algún grado o título universitario, o algún título conferido por el Estado, podrían libremente gravar o enajenar sus hijuelas. Aquellos que estuvieran casados con mujeres que supieran leer y escribir, o que tuvieran hijos mayores de 21 años que leyeran y escribieran, podían disponer de sus hijuelas, previa autorización judicial. Pasados diez años de la división de la comunidad, todos los indígenas tendrían la misma facultad, pero con autorización judicial. Por otro lado, todos los miembros de la comunidad podrían solicitar al tribunal la permuta de sus terrenos. Además, se disponía que los indígenas que a la fecha no tuvieran título de merced, serían radicados como colonos en terrenos fiscales. La ley regiría en todas las provincias de Biobío al sur.

La ley distaba de la pretensión original de sus promotores. Especialmente los dirigentes mapuches (encabezados por Aburto Panguilef) lograron que el Senado introdujera en la ley la disposición que mandaba que los juicios entre indígenas y particulares fueran resueltos de manera sumaria por el tribunal especial, en el sentido de restituir las tierras usurpadas a las comunidades. Con ello se estableció un elemento discordante con los intereses de los particulares, que en muchos casos poseían tierras originalmente pertenecientes a las comunidades indígenas.

Paralelamente, se discutió durante 1927 un proyecto de ley sobre constitución de la propiedad austral, que buscaba reemplazar lo dispuesto en 1925. En la presentación del proyecto, del 14 de enero de 1927, el Gobierno dejaba claro que respondía a las presiones de los agricultores y parlamentarios del sur:

“el Gobierno no puede desentenderse de la resolución que en esta materia se le exige, por lo que representa en calidad y en número ese núcleo formidable de cultivadores de la tierra que tras esfuerzos titánicos y de cruentos sacrificios, han aguardado pacientemente el transcurso de más de medio siglo para que se les otorgue el título de propiedad de las tierras en que muchas veces han visto morir a sus antepasados y en la que han logrado formar dominios cultivados de suelos a los que, cincuenta años atrás, era casi imposible que penetrara el ser humano" 83 .

Como en el caso del proyecto de ley de división de las comunidades indígenas, el Gobierno hacía una presentación parcial e interesada de la cuestión. Se olvida-

82 El reglamento de la ley, de 4 de julio de 1928, señaló que la división se haría por la petición de cualquier comunero. Lipschütz, op. cit., 157.

83 Ureta, op . cit., 251-252. 
ban las usurpaciones de tierras, especialmente a indígenas, y el modo fraudulento en que se habían constituido muchas propiedades.

De este modo, el Gobierno elaboró un proyecto favorable a los agricultores: el Estado reconocería como válido cualquier título anterior a 1874 y 1893, fecha de las prohibiciones para comprar tierras a indígenas. Además, los títulos con fechas posteriores serían anotados ante el Estado y este tendría 4 años para demandar judicialmente a sus poseedores, pudiendo darlos por buenos sin juicio vía un decreto presidencial. Iniciado un juicio, el tribunal reconocería el dominio particular si hubiera una ocupación continuada por más de diez años e inversiones. También, se permitiría a los ocupantes de tierras, con una posesión continuada de algunos años, adquirir esas tierras por cesión o compra al Estado. Poco importaban los derechos de los indígenas y del Estado, dueños originales de todas las tierras del sur.

Los diputados que apoyaban el proyecto, entre julio y agosto de 1927 , reclamaron urgencia en la solución del problema de títulos que afectaba a los agricultores, atendiendo al "esfuerzo" con el que habían incorporado esas tierras a la economía nacional. Ellos tenían todo para progresar, faltándoles solo ser reconocidos como verdaderos propietarios. Este era su único obstáculo ${ }^{84}$. Por su parte, hubo una fuerte oposición de algunos diputados para aprobar por ley todas las usurpaciones y abusos cometidos. Debían ser los particulares quienes demostraran sus derechos y no el Estado el que demandara judicialmente o reconociera títulos con total liberalidad. Además, creían que no bastaba con solo establecer los derechos de los particulares respecto al Estado, sino que había que resolver los conflictos entre particulares. A pesar de esta oposición, se impuso la tesis del Gobierno y de los diputados del sur; a favor de reconocer propiedad a cualquiera que tuviera títulos anteriores a las leyes de prohibición, a los que tuvieran títulos posteriores y una ocupación continuada y productiva, y ceder o vender a los ocupantes que demostraran haber poseído tierras por un tiempo.

Los reparos presentados por algunos diputados al proyecto fueron escuchados por el gobierno de Carlos Ibáñez del Campo, quien dispuso en septiembre de 1927 detener su tramitación hasta hacer las modificaciones necesarias. Por ese momento, ya estaba tratándose el proyecto en el Senado, el que había aceptado lo fundamental del proyecto y procedía a corregirlo en la forma ${ }^{85}$. Por esta época, con el inicio de la dictadura de Ibáñez, el Parlamento perdió su independencia para resolver este asunto y se impuso generalmente la voluntad del Gobierno. Mientras se preparaba un nuevo proyecto, en septiembre se volvieron a prorrogar los plazos de la ley de 1925, hasta 1928. En la práctica, a la espera de una reforma integral de lo existente, los propietarios de tierras no estaban cumpliendo estas disposiciones.

El 27 de septiembre de 1927 el Gobierno hizo llegar al Senado un nuevo proyecto sobre lo señalado ${ }^{86}$. El Presidente reconocía la importancia económica que

84 Cámara de Diputados, Boletín de Sesiones, 1927, 938-959, 1.064-1.067, 1.094-1.108, 1.209, $1.432-1.455,1.585-1.605,1.637-1.646$ y $1.672-1.700$.

85 Senado, Boletín de Sesiones, 1927, 1.249-1.257 y 1.338-1.362.

86 Senado, Boletín de Sesiones, 1927-1928, 12-18. 
involucraba la pronta solución del asunto, pero sin que ello lesionara los intereses fiscales. Se declaraba la vigencia de las leyes que regularon y prohibieron el comercio de tierras en el sur, en 1866 y 1874, por lo que después de esas fechas ningún título era válido. Además, se afirmaba, por las leyes de prohibición de 1874 y 1893 eran nulas hasta la mera tenencia de terrenos indígenas. Por ello, era absurdo que el Estado, legítimo dueño, fuera el que demandara a los particulares, como se disponía en el proyecto anterior, y reconociera derechos a propietarios que adquirieron tierras con posterioridad a esas fechas.

Esta vez el Gobierno favorecía la defensa de las tierras fiscales, en parte atendiendo las demandas hechas directamente al presidente Ibáñez por Manuel Aburto Panguilef. Para los indígenas, la pérdida de todas las tierras fiscales del sur, a manos de los particulares que se las habían apropiado, impediría la radicación de los indígenas que no tenían títulos sobre las tierras que ocupaban. Tampoco les permitiría acceder al beneficio que les concedía la ley de división de comunidades, de optar a ser considerado colono en tierras fiscales si la parte recibida en la división no era de su agrado ${ }^{87}$. De allí su interés por los contenidos de la ley sobre constitución de la propiedad austral.

Sin embargo, el Gobierno, con criterio pragmático, señalaba en su mensaje al Senado que cedería o vendería tierras a los particulares, en condiciones ventajosas. El Gobierno tenía una ilusión, al creer que podría obtener un suculento beneficio por esta vía. Más adelante, se fue convenciendo lentamente de que la única opción posible era reconocer el dominio que de hecho tenían los particulares, olvidándose del beneficio fiscal.

El procedimiento propuesto era una solución administrativa del asunto. Todos los que tuvieran derechos sobre tierras al sur del río Malleco, deberían registrar sus títulos en el plazo de dos años ante una repartición gubernamental. El Presidente de la República tendría un año, contado desde la anotación, para declarar la validez de los títulos. Se reconocerían como válidos los que emanaran del Estado, los que tuvieran una sentencia judicial favorable y los inscritos con anterioridad a las leyes de prohibición de 1874 y 1893, según la zona. Los que no obtuvieran el reconocimiento de sus títulos, podrían solicitar la cesión de esos terrenos, previa demostración de una ocupación de varios años, o comprarlos, si probaban haber pagado contribuciones por esas tierras desde 1921. Los que no quedaran conformes con la decisión del Presidente, podrían demandarlo judicialmente.

A pesar de que el Gobierno planteaba que el Estado era el dueño de todas las tierras del sur, después de 1874 y 1893, según el caso, el trámite administrativo dispuesto y la enormidad de títulos existentes hacían difícil creer que los funcionarios gubernamentales fueran acuciosos en la revisión de la documentación y en la defensa de los intereses estatales. Era conocido que en el sur se habían fabricado por décadas títulos que carecían de valor real. Por otro lado, era extraño que el Gobierno fuera a revisar todos los títulos, siendo que muchos de ellos provenían del Estado o estaban sancionados por resolución judicial.

87 Cámara de Diputados, Boletín de Sesiones, 1927-1928, 169-175. 
Con pequeños cambios la nueva ley se promulgó el 11 de febrero de $1928^{88}$.

Sin embargo, las presiones de los agricultores y el interés de terminar a corto plazo con el asunto llevaron al Gobierno a realizar a fines de 1928 una reforma a esta ley, flexibilizando los criterios y procedimientos establecidos para la constitución de la propiedad y dando mayores derechos a los ocupantes, la que fue promulgada el 28 de diciembre de este año. Aún quedaron aspectos sin resolver para los parlamentarios, especialmente expuestos por los diputados, como la improcedencia de exigirles anotación de sus títulos a los que los habían recibido del Estado, pero predominó la voluntad del Gobierno y esos cambios no prosperaron en ese momento ${ }^{89}$.

En la segunda mitad de 1928 comenzaron a funcionar las comisiones provinciales, entre ellas las de Angol, Temuco y Valdivia, ante las que se realizarían los trámites dispuestos por la ley. El criterio del Gobierno era avanzar rápido, pero evitando cometer errores. En agosto el ministro de Fomento envió una nota a los funcionarios encargados para que cuidaran que los títulos anotados no incluyeran terrenos de indígenas, pues de lo contrario el tribunal especial existente podría terminar desalojando a los particulares.

Que el Gobierno ya se hallaba cansado con el asunto y quería darle un corte definitivo, lo demuestra la siguiente nota del ministro de Fomento al intendente de Valdivia, de fines de agosto:

"el ministerio de mi cargo, dentro del propósito de que en el menor tiempo posible y con el menor gasto para los interesados, pueda efectuarse la revisión y calificación de los títulos de la propiedad austral, ha resuelto dar todas las posibilidades que sean posibles, en cuanto no perjudiquen la debida calificación y estudio de esos títulos"90.

Las facilidades se referían a presentar variados documentos probatorios del título, en el caso de los emanados del Fisco, que los planos exigidos fueran hechos por el Fisco, solo cobrando el costo material, y que el Gobierno había pedido a las instituciones financieras que tuvieran documentos de títulos que los prestaran para copiarlos.

Más adelante, el ministro de Fomento les solicitó a los intendentes que visitaran las oficinas encargadas de la constitución de la propiedad austral, ya que el Gobierno quería acelerar todo lo posible la regularización de la propiedad en el sur ${ }^{91}$.

Por otro lado, el Consejo de Defensa Fiscal declaraba por noviembre que en la anotación de títulos solo debía constatarse la fecha y procedencia del título, pero no correspondía examinar su legalidad, ya que la ley no lo ordenaba92. De este modo, la anotación se convertía en un mero trámite.

88 Ibid., 2.321-2.388 y 2.428-2.437, 2.439 y 2.451-2.466; y Senado, Boletín de Sesiones, 1928, 29.

89 Cámara de Diputados, Boletín de Sesiones, 1928-1929, 2.400-2.405, 2.708-2.713, 2.836-2.864, 2.939-2.942, 2.991-2.999, 4.246-4.247 y 4.302-4.315; Senado, Boletín de Sesiones, 1928-1929, 1.764$1.766,1.839,2.015-2.019,2.053$ y 2.151 .

90 Citado por el diario Chile Austral, 21 de agosto de 1928.

91 Idem, 4 de octubre de 1928.

92 Idem, 7 de agosto y 27 de noviembre de 1928. 
Hacia junio de 1929 los resultados eran escasos. Menos del 10\% de las solicitudes presentadas habían sido resueltas ${ }^{93}$. Quizá por el considerable trabajo que restaba, por esa fecha el Gobierno había ordenado a las comisiones provinciales no revisar los títulos dados por el Estado. Todo indicaba que se requería una reforma que permitiera alcanzar a corto plazo el objetivo de "constituir la propiedad austral". En agosto el Senado comenzó a tratar una reforma ${ }^{94}$. Se aprobó: eliminar la exigencia de anotar los títulos emanados del Estado (mercedes a indígenas, remates y concesiones); reconocer como válidos títulos sobre acciones y derechos, que hasta la fecha eran rechazados; la ocupación de tierras exigida sería la del solicitante o la realizada por otro a su nombre; rebaja de la sanción a los que no anotaran sus títulos; se facultaba al Presidente de la República para reconocer títulos por situaciones especiales, siempre que hubiera ocupación de diez años; ampliación de los plazos establecidos por la ley hasta junio de 1930; y se autorizaba al Presidente para entregar la aplicación de la ley a funcionarios u organismos especiales. En la Cámara de Diputados, en septiembre, las reformas propuestas fueron aprobadas en su totalidad, aunque no faltaron los diputados que recordaron todas las veces que se había legislado sobre la misma materia y que cada vez que se hacían reformas se decía que ahora sí eran las mejores y definitivas ${ }^{95}$. Sin embargo, como varios denunciaban, todavía quedaban aspectos sin resolver; por ejemplo, los conflictos entre particulares. Mientras no se legislara sobre esto ninguna propuesta sería suficiente. A pesar de esos reparos, a petición del Gobierno, que era consciente de lo que estaba pendiente pero creía que había que avanzar por etapas, se terminaron aprobando las reformas el 25 de septiembre de 1929.

\section{El Ministerio de Propiedad Austral, 1929-1931}

El Gobierno creó un ministerio especial, llamado de Propiedad Austral, el 31 de octubre de 1929, para atender lo relacionado con la propiedad austral y con los indígenas. Fue planteado como un ministerio transitorio, especialmente para agilizar la anotación de títulos y la venta y cesión de tierras fiscales. Para su funcionamiento se crearon oficinas en cada una de las principales ciudades del sur de Chile. Además, el propio ministro viajaría regularmente a la zona, para entrevistarse con funcionarios, autoridades e interesados.

El decreto que creó el Ministerio de Propiedad Austral (MPA) justificó la medida, entre otras razones, por:

"2. Que la complejidad de los problemas que, en cada caso, deben ser resueltos, la extensión territorial afectada por esta ley, que alcanza aproximadamente a veinte millones de hectáreas, y el número de títulos que deben ser estudiados -cerca de cuarenta y

$93 \quad$ Idem, 17 y 21 de junio de 1929.

94 Senado, Boletín de Sesiones, 1929, 784-785 y 886-891.

95 Cámara de Diputados, Boletín de Sesiones, 1929, 1.799-1.780, 1.907-1.909, 1.961-1.985, 2.001-2.003, 2.030-2.031 y 2.293-2.299. 
siete mil- exige la constitución de un organismo especial que se encargue exclusivamente del examen cuidadoso de las diferentes situaciones producidas en esa zona.

3. Que hay verdadero interés público en dar término, a la brevedad posible, a la situación de incertidumbre que reina en dicha región acerca de la validez de los títulos de propiedad, para que los agricultores puedan disponer sin dificultad del crédito y demás facilidades necesarias al fomento y desarrollo de la producción agrícola.

4. Que la trascendencia social y jurídica de los problemas relacionados con la ley sobre propiedad austral y radicación de indígenas, exige que los organismos encargados de su estudio estén presididos por un funcionario que comparta las responsabilidades del Ejecutivo en las resoluciones que determine la aplicación de estas leyes"96.

Este organismo duraría, según el decreto, hasta el 31 de diciembre de 1932, lo que manifestaba el interés de resolver con rapidez las tareas encomendadas.

A principios de noviembre comenzó a organizarse la planta y departamentos del ministerio. Respecto a las inhabilidades, un decreto ministerial del 11 de noviembre de 1929 estableció que no podían participar en el personal quienes tuvieran intereses relacionados con la propiedad raíz afecta a la ley de propiedad austral, impedimento que se hacía extensivo a los parientes cercanos ${ }^{97}$. El ministerio tendría nueve oficinas: Santiago, Cañete, Angol, Temuco, Valdivia, Villarrica, Osorno, Puerto Montt y Ancud, siendo las más importantes las de Temuco y Valdivia. En cada una de ellas habría funcionarios del departamento de mensura de tierras. Solo habría departamento jurídico en Santiago, Valdivia, Puerto Montt y Ancud ${ }^{98}$.

En definitiva, hacia marzo de 1930, había seis oficinas: Angol, Temuco, Valdivia, Osorno, Puerto Montt y Ancud, fuera de tres delegaciones (en Contulmo, Pitrufquén y Castro) dependientes de las oficinas de Angol, Temuco y Ancud ${ }^{99}$. En abril de 1930 se estableció una delegación de la oficina de Osorno en La Unión ${ }^{100}$.

La creación del MPA supuso la detención de los desalojos de colonos y ocupantes en el sur, tal como lo solicitó el ministro del ramo al del Interior, en noviembre de 1929101.

Por otro lado, desde fines de 1929 se discutía en el Parlamento una reforma a la ley de comunidades indígenas, ya que esta había ocasionado serios conflictos con la legislación de la propiedad austral. Como se verá más adelante, en enero de 1930 se aprobó una nueva ley sobre comunidades indígenas ${ }^{102}$. En cuanto afectaba a los propietarios no indígenas, esta ley estableció que en el caso de las restituciones de los terrenos que eran parte de una comunidad, los títulos de indígenas prevalecerían excepto cuando el ocupante tuviera un título del Estado, o uno de

\footnotetext{
96 Ministerio de la Propiedad Austral, Boletín No 1, diciembre de 1929, 24-26.

97 Ibid., 39

98 Idem.

99 Ministerio de Propiedad Austral, Boletín N ${ }^{\circ}$ 2, enero-marzo de 1930, 126-127. Respecto a la oficina de Puerto Montt, en un principio no se le dio competencia sobre Aisén; recién una orden ministerial del 3 de abril de 1930, amplió la jurisdicción de Puerto Montt hasta el territorio de Aisén.

100 Ministerio de Propiedad Austral, Boletín N ${ }^{\circ}$ 4, julio-septiembre de 1930, 7-19; y diario Chile Austral, 14 y 23 de abril de 1930.

101 Ministerio de Propiedad Austral, Boletín $\mathrm{N}^{\circ} 1$, op. cit., 127.

102 Ministerio de Propiedad Austral, Boletín $\mathrm{N}^{\mathrm{o}} 2$, op. cit., 8-16.
} 
origen particular anterior a la merced y aprobado por el MPA. Si la aprobación estuviera pendiente, se esperaría el pronunciamiento del Presidente de la República. En el caso del ocupante, se le radicaría en un predio de valor equivalente a aquel que debía restituir, e incluso se le pagarían las mejoras si tuviera un título del Estado posterior a la merced. Como se ve, las resoluciones estatales favorecían principalmente los derechos de los particulares.

Dado el enorme trabajo por realizar, y los limitados plazos, la búsqueda de la eficiencia fue una necesidad para el ministerio. Por ejemplo, una orden ministerial, del 7 de enero de 1930, mandaba que los jefes de departamentos, subdepartamentos y el inspector general de agrimensores dejaran constancia al final de cada informe del tiempo que había demorado el trámite en esa oficina ${ }^{103}$. El 3 de abril de 1930 una circular eliminó la exigencia de que los planos se presentaran con firma de un titulado, pudiendo hacerlo cualquiera, siempre que respetara los requerimientos técnicos. Otra orden, del 17 de junio de 1930, suspendió todos los feriados legales y permisos hasta no haber cumplido la mitad del trabajo encomendado por la ley ${ }^{104}$. Además, una orden del 18 de julio de 1930 mandó que ningún expediente estaría más de cuatro días hábiles en un departamento (mensura de tierras, jurídico y conservador de títulos y planos) ${ }^{105}$.

A principios de 1930 en el MPA se estaban estudiando tres ideas para avanzar en la solución de sus obligaciones, a saber: 1) reconocimiento de la validez de títulos en un breve plazo, después del cual caducaran las acciones que pudieran hacer terceros. Esto es, una prescripción de corto plazo. 2) Autorizar a las instituciones hipotecarias para prestar dinero a los propietarios que hubieran realizado los trámites para la constitución de la propiedad ante el Presidente de la República. 3) Sanear los vicios que hubiera en transacciones con indígenas, siempre que hubiera treinta años de posesión material y se acreditaran trabajos y mejoras en dichas tierras.

Para controlar el trabajo en terreno, entre el 14 y el 16 de mayo de 1930 estuvo en Temuco, Valdivia y Osorno el ministro Edecio Torreblanca, visitando las dependencias de su repartición, oficinas de la propiedad austral y juzgados de in$\operatorname{dios}^{106}$

El 18 de mayo hubo en Osorno una Asamblea Interprovincial de Agricultores, con la presencia del ministro Torreblanca. Urrutia Ibáñez, a nombre de los propietarios rurales, señaló que entre los problemas más apremiantes estaba: "El de la constitución de la propiedad raíz, que se retarda indefinidamente y que es motivo de inquietudes, molestias, grandes gastos y aun de lágrimas para los propietarios más legítimos"107. A su juicio, al ritmo actual ni en treinta años se terminaría con el problema. Desde 1925 no se habían constituido más de mil títulos, calculando que existían unos 40 mil en toda la zona, por lo que en dos años era imposible acabar con lo propuesto.

\footnotetext{
103 Ibid., 87.

104 Ministerio de Propiedad Austral, Boletín No 3, abril-junio de 1930, 232-233 y 256.

105 Ministerio de Propiedad Austral, Boletín $\mathrm{N}^{\circ}$ 4, op. cit., 131.

106 Chile Austral, 16 de mayo de 1930.

107 Idem, 19 de mayo de 1930.
} 
Torreblanca le respondió que antes de tres años estaría todo listo, pues los trámites se estaban simplificando. La asamblea insistió en que se hicieran llegar al Parlamento los proyectos que se estudiaban en el ministerio para facilitar el proceso ${ }^{108}$.

Por esa misma fecha, en su cuenta anual ante el Congreso, el Presidente era muy optimista frente al tema, señalando:

"la aplicación de dicha ley no ha presentado en la práctica dificultades apreciables, de modo que no habrá necesidad de modificar sus disposiciones. En general esa ley, sin desconocer los derechos legalmente establecidos reconoce el valor del trabajo de los que han hecho prósperos con su esfuerzo honrado esas ricas regiones" 109 .

A fines de junio de 1930 venció el plazo para pedir reconocimiento de validez de títulos. Recién una ley de diciembre de ese año determinó que el plazo final sería el 3 de enero de 1931 y declaró válidas las presentaciones hechas entre junio de 1930 y la fecha de la ley. También, se rebajó la antigüedad a 1928 para los ocupantes que pidieran título gratuito y las exigencias para ocupantes que pidieran venta de tierras, y se agregaron a los títulos que serían reconocidos como válidos aquellos no emanados de indígenas con una inscripción anterior a 1900. Todo ello dio mayores facilidades a los particulares. La misma ley excluyó del trámite de reconocimiento de validez de títulos a las propiedades menores a 100 hectáreas de la provincia de Chiloé y del ex departamento de Carelmapu, en la provincia de Llanquihue ${ }^{110}$.

A fines de julio de 1930 se produjo un cambio importante en la planta del Ministerio de Propiedad Austral, tras pasar a este el departamento de Tierras y Colonización del Ministerio de Fomento y la oficina de Bienes Nacionales del Ministerio de Hacienda. Además, aumentaron las oficinas de la propiedad austral, con la creación de las de Magallanes y de Aisén ${ }^{111}$. Con todo ello las actividades del MPA aumentaron significativamente. Fuera del tema de la propiedad austral y comunidades indígenas, debió preocuparse de las reservas forestales, de lo relativo a pesca y caza, del arrendamiento de terrenos fiscales y del catastro de los bienes fiscales, con lo que su ámbito de acción se extendió a todo el país.

En octubre de 1930, a pesar del avance logrado en estas materias, Urrutia Ibáñez describía en la prensa valdiviana un cuadro patético de la agricultura sureña; afectada por los bajos precios del trigo y avena, un aumento del costo del flete de madera, cereales y animales destinados al centro del país, falta de crédito hipotecario a largo plazo por la inconclusa constitución de la propiedad austral, altos intereses en los préstamos de breve plazo y, sumado a todo ello, los gastos de dinero y tiempo en los trámites ante las oficinas de la propiedad austral.

Por su parte, el abogado Luis Morales Zuaznábar salió al paso de Urrutia, rebatiendo sus planteamientos. Señalaba que las condiciones dadas por la ley eran

\footnotetext{
108 Idem, 21 y 23 de mayo de 1930.

109 Idem, 23 de mayo de 1930.

110 Instituto Nacional de Asuntos Indígenas, op. cit., 82-83.

111 Ministerio de Propiedad Austral, Boletín $\mathrm{N}^{\mathrm{o}} 4$, op cit., 19-28.
} 
las mejores y que en Valdivia la solución legal se aplicaba con rapidez, habiéndose despachado los títulos de casi la mitad de todo el departamento ${ }^{112}$.

En definitiva, entre noviembre de 1929 y diciembre de 1930, el MPA resolvió: 2.394 solicitudes por títulos gratuitos, por $56.616,06$ hectáreas; 762 por reconocimiento de validez de títulos, por $696.149,72$ hectáreas; 61 por ventas directas, por 26.395,41 hectáreas; 159 por temas varios, por 767.599,17 hectáreas. En total, se dictaron 3.376 decretos por 1.546.760,3 hectáreas ${ }^{113}$.

La eficiencia del MPA se puede ver, por ejemplo, en la actuación de la oficina de Valdivia. En abril de 1931, fuera de haberse hecho cargo de las actividades del ex departamento de Tierras y Colonización, había recibido solicitudes por más del $90 \%$ de la superficie del departamento: unas 2.712 presentaciones (1.382 para reconocimiento de validez de título, 589 pidiendo título gratuito y 25 de venta directa, fuera de otras consideradas varias). Del terreno restante, había una parte que era fiscal, por lo que era ínfimo el número de propiedades que no habían hecho los trámites legales. Para una buena parte de las solicitudes faltaba hacer los informes técnicos, por lo que solo se habían despachado a Santiago 1.520 de ellas.

En los primeros meses de 1931 se dictaron varias leyes a favor de los propietarios del sur. A principios de año, una para permitir que los particulares que tuvieran títulos del Estado o reconocidos por el Ministerio de Propiedad austral optaran a créditos hipotecarios, que dispuso que lo podrían hacer solicitando una autorización judicial. Si hubiere otros pretendientes a los terrenos en cuestión se presentarían ante el juez para defender sus derechos. Si no los hubiera, o se rechazara la oposición, el juez daría autorización para hipotecar. Con ello, la institución crediticia se aseguraba de que cualquiera que fuera el futuro dueño, la deuda tendría que ser pagada. Por abril se volvió a reformar la ley de propiedad austral, ampliando el plazo para realizar trámites ante el MPA hasta el 31 de diciembre de 1931.

Por fin, el 20 de mayo de 1931 se dictó una ley que se venía esperando por cerca de un año, que estableció la prescripción en dos años a favor de los que hubieran obtenido reconocimiento de su título o uno de parte del Estado. Esta ley venía a consolidar la acción del MPA y a resolver definitivamente los conflictos entre particulares, permitiendo a los propietarios poder solicitar sin dificultades créditos hipotecarios, pues el Estado con su sanción avalaba la legalidad del dominio. Entre los considerandos de esta ley, se planteaba:

"que puede partirse, al efecto, de una presunción que casi siempre corresponde a la realidad de las cosas, la de que la persona que está en posesión de la tierra y cuyos títulos han sido reconocidos como válidos por el presidente de la República, o ha obtenido que el Estado le venda o conceda gratuitamente el terreno que ocupa, es el verdadero dueño" 114 .

\footnotetext{
112 El Correo de Valdivia, 28 de octubre de 1930.

113 Idem, 18 de junio de 1931.

114 Instituto Nacional de Asuntos Indígenas, op . cit., 97.
} 
Como se ve, el Gobierno partía del principio de que quien tenía los títulos y poseía las tierras era siempre el verdadero dueño. Tal norma, aunque vulneraba el derecho civil común, según el Gobierno era la única forma de poner fin a la incertidumbre existente entre los propietarios del sur de Chile, desde Malleco hasta Aisén.

El mismo 20 de mayo se modificaron las disposiciones vigentes sobre comunidades indígenas y jueces de indios, ampliando las atribuciones del MPA, el que debía asumir la defensa de los indios en los casos de segunda instancia ante la Corte de Apelaciones de Temuco y resolver las disputas de competencia entre los jueces de indios ${ }^{115}$.

Por último, en junio de 1931, antes de la fecha establecida al momento de su creación, el Ministerio de la Propiedad Austral cesó, siendo reemplazado en el futuro en todas sus tareas por el de Tierras y Colonización ${ }^{116}$.

Tras el cambio político de julio de 1931, con la caída de Ibáñez, dictadas las leyes comentadas que favorecieron a los propietarios rurales del sur, el problema de la propiedad austral dejó de ser una polémica pública y perdió presencia política. Una muestra de la pérdida de interés por el problema se evidenció en la visita a la región, en diciembre de 1931, del ministro de Tierras y Colonización, Teodoberto Álvarez. Entrevistado por la prensa valdiviana, ninguna de sus declaraciones se refiere al asunto de la constitución de la propiedad austral, más bien sus preocupaciones iban dirigidas a recorrer la zona para entregar a colonos las pocas tierras fiscales que quedaban y procurar la compra de algunos fundos con ese mismo fin ${ }^{117}$.

Se había cumplido con una solución administrativa muy favorable a los intereses de los propietarios rurales sureños, pero bajo las decisiones ministeriales el problema de fondo continuó pendiente. Parte de la acción ministerial, por la enormidad de papeles revisados y por los breves plazos de estudio, fue desacertada, por lo que viejos y nuevos conflictos relacionados con la propiedad de la tierra continuaron como querellas entre particulares e indígenas.

\section{LOS ESFUERZOS POR ACABAR CON LAS COMUNIDADES INDÍGENAS, 1927-1935}

Después de todos los cambios hechos a la ley de propiedad austral, que manifestaban el interés del Estado por consolidar la propiedad rural no indígena en el sur de Chile, era lógico que se realizaran reformas a la ley de división de comunidades indígenas ${ }^{118}$.

Hacia julio de 1929, el tribunal especial creado en 1927 para dividir las comunidades había avanzado poco en su labor principal. Según su presidente, Ciro

115 Idem, 101-110.

116 El Correo de Valdivia, 18 de junio de 1931.

117 Idem, 10 de diciembre de 1931.

118 Sobre el intento de acabar con las comunidad indígenas, ver Fabián Almonacid, "La división de las comunidades indígenas del sur de Chile, 1925-1958: un proyecto inconcluso", en Revista de Indias LXVIII: 243, Madrid, mayo-agosto de 2008, 115-150. 
Salazar, no contaba con el apoyo técnico necesario para cumplir con sus tareas. Solo disponía de cuatro agrimensores y requería a lo menos veinte para levantar los planos de las 500 mil hectáreas que estaban dentro de su competencia. No eran más de tres las comunidades que habían sido divididas, mientras quedaba un considerable número de expedientes en tramitación: 1.709 solicitudes de partición e inscripción de títulos y 1.216 reclamos de restitución de tierras ${ }^{119}$.

El tribunal había generado malestar entre los agricultores del sur de Chile, pues procedía sin juicio a restituir los terrenos de las comunidades que estaban en poder de particulares. Por febrero de 1929, unas 1.653 hectáreas habían sido devueltas a los indígenas ${ }^{120}$. Ello solo era el comienzo, pues no había comunidad que no hubiera perdido terrenos a manos de usurpadores. El propio tribunal se daba cuenta de que no podía más que cumplir la ley, sin considerar las diversas situaciones; junto a los verdaderos usurpadores, había ocupantes de buena fe, que recibieron títulos del Estado o que compraron a particulares tierras que ya incluían esos terrenos. Por ello, el Gobierno ordenó detener las restituciones hasta que se resolvieran las reformas a la ley de propiedad austral. Así, en la práctica el tribunal no funcionaba plenamente.

Por su parte, el escaso avance en la división de las comunidades generó una campaña en los periódicos del sur, que destacaba el abandono en que se encontraban las tierras en manos de indígenas y la necesidad de que esos terrenos se incorporaran a la economía regional y nacional ${ }^{121}$.

Así, las presiones de los particulares afectados por las restituciones; el interés porque se pusiera fin a las comunidades indígenas; la mayor liberalidad introducida en el reconocimiento de títulos y derechos de ocupantes particulares; y la propia opinión del tribunal, favorable a moderar la restitución de terrenos indígenas, conciliando los derechos de particulares e indígenas, según cada caso, llevaron a una reforma de la ley de 1927. A fines de 1928 el Gobierno presentó a la Cámara de Diputados un proyecto para reconocer los derechos de los ocupantes de tierras indígenas que tuvieran un título anterior al de merced indígena. Se pretendía que antes de la orden de restitución del tribunal especial, el particular pudiera interponer un recurso ante la justicia ordinaria, la que resolvería ${ }^{122}$. Tal medida no fue concretada, pues se optó por una reforma completa de la ley. El Gobierno, el tribunal especial y los protectores de indígenas prepararon un proyecto, que fue enviado al Parlamento a comienzos de 1929.

Según los críticos del tribunal, este carecía de capacidad jurídica para resolver materias tan delicadas, dado que solo uno de sus miembros era letrado. Era materialmente imposible que resolviera rápidamente la división de las comunidades. De paso se dudaba de la imparcialidad del dirigente mapuche que lo integraba. Más que eso, creemos, se rechazaba la atribución de poder restituir los terrenos usurpados a los indígenas y su composición, en principio favorable a los indígenas. Sin

\footnotetext{
119 Cámara de Diputados, Boletín de Sesiones, 1929, op . cit., 726.

120 Foerster y Montecino, op. cit., 79.

121 Cámara de Diputados, Boletín de Sesiones, 1929, op. cit., 813.

122 Cámara de Diputados, Boletín de Sesiones, 1928-1929, op . cit., 2.403-2.405.
} 
embargo, estas críticas no podían ser expresadas directamente, pues el tribunal gozaba de un apoyo general entre las organizaciones mapuches y contaba con la confianza de los misioneros capuchinos. Se le tenía por un tribunal honorable. De tal manera, como no podían descalificar al tribunal, se atacó directamente a la ley.

Un misionero capuchino lamentó la reforma, pues perjudicaba la pronta división de las comunidades, objetivo prioritario para ellos camino a la civilización del indígena. Como planteaba en El Diario Austral, de Temuco, en febrero de 1929:

“el araucano recibirá dentro de poco plazo el dominio definitivo de su terreno [...] porque el indígena esforzado y trabajador surgirá una vez que se acabe su indigno estado de menor de edad y sus tierras producirán [...] y el flojo y el perezoso perdería irremediablemente todo y entonces su propiedad pasará a manos más productivas" ${ }^{123}$.

Los detractores de la ley vigente tenían buenos representantes en el Congreso. En un principio se pretendía modificar la atribución de restitución de tierras y agilizar la división de comunidades estableciendo que la realizaran los protectores de indígenas, dejando al tribunal solo para resolver las situaciones de mayor importancia. Sin embargo, una comisión especial de la Cámara de Diputados se abocó a estudiar una reforma integral, entre febrero y junio de $1929^{124}$.

La comisión concluyó que la labor del tribunal era deficiente y convenía eliminarlo. Se argumentó que era mejor tener un tribunal de derecho. El Gobierno apoyó su reemplazo. El 7 de junio el diputado Manquilef propuso que se crearan jueces de indígenas. Se pensó que estos nuevos tribunales serían transitorios, mientras se realizara la división de las comunidades, por lo que se daría facultad al Presidente de la República para suprimirlos cuando hubieran terminado su labor. Por otro lado, se discutió en detalle el tema de las restituciones; hubo acuerdo en que se debía respetar a los ocupantes, prefiriendo su permanencia en el dominio de los terrenos indígenas cuando tuvieran títulos anteriores al título de merced o pagándole sus mejoras, en el caso de que se les desalojara. El diputado Domingo Durán señaló, el 11 de junio, que el progreso de la región se debía a los ocupantes y que no era justo que se les privara del producto de su esfuerzo ${ }^{125}$. Respecto a la permanencia o no del ocupante en tierras indígenas, el ministro de Fomento propuso que en última instancia decidiera el Presidente de la República. Para facilitar ello, el ministro planteó que el Presidente pudiera expropiar los terrenos restituidos o por restituirse, en los casos que hubiere interés en que permaneciera el ocupante. Con el valor resultante de la venta del terreno al particular se podría compensar a los indígenas.

Desde julio de 1929 la Cámara de Diputados pasó a tratar la reforma ${ }^{126}$. Se decidió que los juzgados de indios, como se les llamó, conocerían en única instan-

123 Citado por Foerster y Montecino, op. cit., 63-64.

124 Cámara de Diputados, Boletín de Sesiones, 1929, op. cit., 2.317-2.344.

125 Ibid., 2.333.

126 Cámara de Diputados, Boletín de Sesiones, 1929, op. cit., 715-731, 761-779, 799-820, 849857 y $1.911-1.932$. 
cia materias relacionadas con la división y en primera instancia las relativas a restituciones. El diputado Héctor Álvarez fue uno de los pocos que se opuso a sancionar el despojo de las tierras indígenas y a impedir que los indígenas pudieran apelar a los fallos del juez de indios por asuntos entre indígenas. A su vez, el diputado Abraham Quevedo no estuvo de acuerdo con validar los títulos fraudulentos de los particulares.

Hubo un intenso debate sobre si debían o no ser apelables todas las sentencias de los jueces. El Gobierno terminó incorporando la existencia de abogados procuradores para los indígenas, para ayudarlos en las cortes de apelaciones en los juicios con particulares. En la indicación, de comienzos de julio, el ministro de Fomento señalaba: "no hay, en realidad, ningún título de merced que no tenga cuestiones con particulares"127.

Se aceptó que el Presidente de la República tuviera la facultad de expropiar terrenos de indígenas ocupados por particulares, aunque hubo dudas pues las nuevas tierras que recibirían los indígenas ya no estarían sometidas a restricciones en el dominio.

A propuesta del diputado Luis Urrutia, que ya había sugerido una idea similar al tratar la ley de propiedad austral, se terminó agregando la obligación del indígena de cercar sus propiedades, pudiendo estas ser embargadas por el incumplimiento de esta norma. El diputado Manquilef, partidario en general del proyecto, se extrañó de la exigencia de poner cercos, especialmente del carácter "civilizador" que Urrutia les daba. Él creía que era imposible pedirle a un indígena que recibiría cuatro hectáreas que pusiera cercos, de valor tan alto en la zona como el de la propiedad.

En la discusión del proyecto se fueron notando vacíos importantes, como el escaso número de funcionarios considerados, producto del interés por economizar del Gobierno, o la dificultad para ofrecer tierras fiscales a los indígenas que habían perdido sus tierras. También, cambios de opinión importantes entre los propios promotores del proyecto, diputados y Gobierno, lo que llevó a un diputado a señalar que ese era el peor proyecto que había pasado a la Cámara. A pesar de todo, el proyecto fue aprobado y pasó en julio al Senado ${ }^{128}$.

La comisión de Agricultura del Senado emitió un informe el 29 de julio de 1929 , apoyando el proyecto. Sus argumentos eran los tradicionales contra la comunidad indígena:

"esta falta de división ha traído como consecuencia el hecho de que esos terrenos no hayan prosperado en la forma que les correspondía ya que los indios, que no tenían un dominio fijo sobre una parte determinada de tierra, sino sobre la totalidad de ella, se negaban a trabajarlas, dejándolas en el más completo abandono"129.

127 Ibid., 799 .

128 Senado, Boletín de Sesiones, 1929, 396-401, 555-561, 585-586, 588-594, 657-665, 681-694, 715-731, 742-759, 787-788, 832-834 y 879-880; y Senado, Boletín de Sesiones, 1929-1930, 32-34, $894,1.071$ y 1.322 .

129 Senado, Boletín de Sesiones, 1929, op. cit., 555. 
El proyecto acabaría con esta dificultad, haciendo comerciables y valorizando los terrenos indígenas. En este informe, la imagen del indio comunitario era la de un ser indiferente hacia la tierra, que despreciaba esas posesiones y no las hacía producir. Por contraposición, el individuo ocupante de tierras indígenas era visto como símbolo de esfuerzo, el verdadero motor del progreso sureño. En este esquema no cabían las comunidades productivas y eficientes, ni los usurpadores de tierras y bienes indígenas, muchas veces enriquecidos después de esas apropiaciones.

La comisión valoraba el reemplazo del tribunal especial, por tener solo un miembro letrado y porque sus fallos de única instancia no permitían corregir "errores". Al revés, los juzgados de indios estarían compuestos por letrados y las sentencias de litigios entre indígenas y particulares serían apelables. Con escasas modificaciones, el proyecto pasó al Senado.

El diputado Manuel Manquilef defendió el proyecto ante el Senado. El 6 de agosto, insistió en la importancia de dividir las comunidades:

"hoy el progreso alcanzado por la región y el contacto directo del indio con el chileno, han formado un espíritu de trabajo, un espíritu de progreso, tanto material como intelectual. Hoy día se necesita [una] ley educativa, una ley que dé estímulo al que algo posee, que eso ha de ser eternamente suyo. Este sentimiento de propiedad, basado en la individualidad, constituye el don más precioso para alcanzar el progreso nacional"130.

Como se aprecia, argumentos opuestos a los de la comisión del Senado, pero concurrentes a un mismo fin. Para el diputado, el indio era trabajador y progresista, por lo que requería liberarse del peso de la comunidad y desarrollar sus fuerzas individuales. Manquilef consideraba que la división de las comunidades era necesaria, recordando que había 500 mil hectáreas en manos indígenas, valoradas en unos 150 millones de pesos, exentas de pago de contribuciones desde 1915, lo que afectaba los planes de inversión en la zona. Una vez constituidas como propiedades individuales, muchas ciudades del sur incrementarían significativamente sus ingresos por el cobro de contribuciones municipales. Esperaba que en no más de cinco años las divisiones estuvieran realizadas. Por último, invitaba a los senadores a aprobar el proyecto: "trabajemos unidos para resolver el problema complicado de una explotación justa y eficaz de nuestros cuantiosos recursos, una explotación que beneficie al mayor número, para que pueda ser la base de una verdadera civilización"131.

Después de esta presentación se leyó una comunicación de dirigentes mapuches de la Unión Araucana y Moderna Araucanía, que desmentía a Manquilef ${ }^{132}$. Como en 1927, el diputado mapuche era contradicho por sus congéneres. En la carta se solicitaba mantener el tribunal especial existente, para evitar que los indígenas perdieran sus tierras, con el conocido pretexto de carecer de espíritu progresista e iniciativa $^{133}$. Agregaban, que la ley de 1927 permitió a muchos indígenas recuperar

\footnotetext{
130 Ibid., 589.

131 Idem.

132 Ibid., 590-583.

133 Ibid., 591.
} 
sus tierras. Sin embargo, rápidamente empezaron las quejas y reclamos de los ricos propietarios afectados por el tribunal. Rechazaban que fuera necesario aumentar el número de jueces, ya que la división de comunidades no requería más que personal técnico suficiente, como había en su momento solicitado el propio presidente del tribunal especial. Creían en la necesidad de la división, pero no compartían el nuevo procedimiento:

"seguimos manifestando que el problema indígena se halla circunscrito en la posesión de sus suelos; ahí está el origen y fin de sus eternas dificultades territoriales. Ahí están los intereses encontrados de estos desamparados de la civilización [...] la familia indígena, día a día más numerosa, va formando núcleos que por las necesidades de la existencia se excluyen mutuamente en sus parcelas de suelo" ${ }^{134}$.

Por todo ello, pedían que no se eliminara el tribunal especial y que se le diera a este mayor apoyo técnico, único modo de evitar que se retardara la división de las comunidades.

Por su parte, el senador Cortés defendió la permanencia del tribunal, apoyándose en informaciones dadas por misioneros capuchinos. Creía que solo era necesario corregir su funcionamiento y señaló que también opinaban a favor del tribunal los ministros de la Corte de Apelaciones de Temuco. Además, otro senador leyó una carta enviada por varios caciques, que defendían al tribunal por haber hecho justicia y devuelto tierras a los indígenas, y consideraban que con la apelación de los juicios entre indígenas y particulares a la justicia ordinaria, los mapuches volverían a ser tratados con la injusticia tradicional.

A pesar de lo señalado, los senadores apoyaron el proyecto, especialmente creyeron que los jueces de indios harían justicia con mayor rapidez y las comunidades se dividirían en breve tiempo. Reafirmando esta conclusión, Manquilef manifestó al Senado, el 13 de agosto, la confianza que los diputados habían puesto en el proyecto, como la única forma de que los indios se incorporaran al progreso nacional, acabando con las diferencias entre indígenas y chilenos ${ }^{135}$. Manquilef sumaba a las supuestas ventajas económicas de la división de comunidades, por el mayor aporte de tierras e indígenas al progreso nacional, la contribución que se haría a la consolidación de la unidad nacional, eliminando la separación del indígena del común de la sociedad nacional.

El Senado hizo algunas correcciones al proyecto. Como por ejemplo, redujo el número de abogados procuradores de los indígenas a tres y separó claramente la resolución en única instancia de los juicios entre indígenas, con informe al Presidente de la República, de los juicios de primera instancia en que se implicara a particulares.

Frente a la posibilidad de radicar en tierras fiscales a los indígenas que no quedaran conformes con las hijuelas recibidas en la partición, algunos senadores manifestaron su extrañeza de que existiera esta opción, ya que dada la pequeñez de

134 Ibid., 593

135 Ibid., 664. 
las hijuelas por recibir, era obvio que los indígenas preferirían ser radicados como colonos, pudiendo recibir hasta cien hectáreas, con lo que en la práctica el Estado no tendría terrenos para todos. Manquilef reconoció que la división de comunidades de menor superficie daría hijuelas de unas tres o cuatro hectáreas y ello sería un fracaso, con lo que pedirían ser colonos. Con estas palabras, quedaba claro que la división no era buena para todas las comunidades. Sin decirlo, Manquilef sabía que muchos indígenas terminarían como mano de obra rural o urbana, o se irían como colonos, dejando sus tierras a otros. Por ello, el senador Hidalgo rechazó que este proyecto de ley fuera favorable al indígena. Si se le daban al indio dos o tres hectáreas terminaría abandonando sus tierras. Así, comentaba, si no se le aseguraba una cantidad mínima de tierras, el proyecto era una burla.

El senador Azócar, a favor del proyecto, señaló que la ley no solo pretendía resolver el problema indígena, sino acabar con las comunidades porque eran instituciones antieconómicas. Los indios no trabajaban las tierras, afirmó, y por ello no prosperaban.

Perplejos quedaron los senadores cuando Manquilef dijo, a propósito de que se disponía que pudieran optar entre una hijuela en la comunidad o por tierras fiscales, que el Gobierno había aclarado que solo había tierras disponibles en la cordillera de los Andes. Ello llevó al senador Irarrázabal a preguntarse qué se ganaba entonces con terminar con las comunidades, si los indígenas acabarían más pobres que antes. Sin desconocer que las tierras indígenas pasarían a otras manos y aumentaría la riqueza general, creía que no se podía decir que lo propuesto fuera justo y protector del indígena ${ }^{136}$.

Otros senadores respondieron que sí había tierras fiscales y que, según se decía, eran los propios indios los que querían dividir las comunidades. El Gobierno tranquilizó al Senado informando que existían tierras disponibles. Manquilef insistió en el objetivo principal, el 20 de agosto:

\footnotetext{
"debo manifestar, eso sí, que en ningún país civilizado han dado buenos frutos las comunidades; en cambio, es el régimen de la propiedad particular el que permite al individuo poner en actividad sus energías, su inteligencia y su fortuna, aunque sea escasa, incrementando la riqueza pública y privada al amparo de las leyes [...] Esta ley persigue el propósito de liberarlos de ese régimen, otorgándoles el derecho de propiedad, a fin de que puedan obtener el fruto de su propio trabajo y satisfacer las necesidades que les imponga la cultura que puedan alcanzar"137.
}

El senador Azócar apoyó a Manquilef, agregando que la ineficacia de las comunidades era un hecho, por lo que la ley los sacaría de esa situación anormal, haciéndolos propietarios de un pequeño terreno, lo que los convertiría en ciudadanos útiles, ya sea como trabajadores de sus propias tierras, o como operarios, inquilinos u obreros ${ }^{138}$. Así, el propósito de la ley era terminar con las comunida-

\footnotetext{
136 Ibid., 693 .

137 Ibid., 716.

138 Ibid., 717.
} 
des por un interés nacional. Azócar tenía menos esperanzas que Manquilef, en un futuro mejor para los indios como propietarios individuales. Poco le interesaba una ley favorable para los indígenas, sino una que contribuyera al progreso nacional.

Finalmente, el 24 de enero de 1930 se promulgó la nueva ley sobre división de comunidades indígenas ${ }^{139}$. Se crearían cinco juzgados de indios, que de oficio procederían a dividir las comunidades con títulos de merced y resolverían en única instancia todo lo relativo a cuestiones entre indígenas, respecto a la división, y en primera instancia en disputas por terrenos comunitarios entre indígenas y particulares. La ley definía que eran "particulares" todas las personas que reclamaran derechos no emanados de un título de merced. Los jueces y demás funcionarios de los juzgados de indios serían nombrados por el Presidente de la República, quien fijaría su sede, jurisdicción y duración. Habría tres abogados procuradores para la defensa de los indígenas. El juez dividiría la comunidad en hijuelas, considerando a los jefes de familia e individuos, o sus sucesiones, mencionados en el título de merced, y entregaría partes diferentes según el número de personas de cada grupo, considerando a los que vivían en el lugar o se presentaran al momento de la división. Los derechos de los ausentes prescribirían cinco años después de la división; mientras tanto se valorizarían en dinero y se hipotecarían las hijuelas por esa cantidad, a prorrata. Los indígenas recibirían tierras en una sola comunidad, al momento de la partición, pero mantendrían sus derechos hereditarios en otras comunidades. Si el indígena no se conformara con la hijuela recibida podría renunciar a ella y pedir que se le radicara como colono en tierras fiscales. Las hijuelas de los que tomaran esta opción serían de propiedad fiscal. Las sentencias de división serían aprobadas por el Presidente de la República. Las hijuelas divididas serían inscritas en el registro del conservador de bienes raíces correspondiente. En el caso de las restituciones de terrenos comunitarios, prevalecería el título de merced, excepto cuando el particular tuviera título anterior dado por el Estado o por particular aprobado por el Ministerio de Propiedad Austral. Los ocupantes que tuvieran que abandonar terrenos indígenas serían radicados en tierras fiscales disponibles. Sin embargo, cuando fuera considerado por el Presidente de la República, a petición del ocupante, que el terreno por restituir fuera útil mantenerlo en poder del ocupante, se expropiaría y vendería a este. Con el dinero resultante se adquiriría otro terreno para la comunidad, en el que no regirían las prohibiciones aplicadas a otros terrenos de indígenas.

Antes de la división, los indígenas podrían de común acuerdo enajenar sus tierras, previa autorización del juez de indios. Hecha la división, los indígenas podrían gravar o enajenar sus hijuelas, arrendarlas por cinco años o hacer contratos de aparcería, también con autorización del juez. No tendrían que pedir esta autorización los que hubieran cursado la educación primaria o tuvieran algún título universitario o de instituto estatal o particular. Además, la ley no exigía solicitar aprobación judicial para cualquier acto o contrato ante las cajas de ahorro y crédito. Las propiedades divididas podrían ser embargadas por impuestos territoriales

139 Instituto Nacional de Asuntos Indígenas, op. cit., 74-81. 
impagos, por deudas bancarias o cobro de gastos de cercado. Diez años después de la ley dictada, los indígenas podrían disponer libremente de sus tierras.

La misma ley suprimió la Comisión Radicadora y los protectores de indígenas, y derogó la mayor parte de la legislación indígena anterior.

Cumpliendo lo dispuesto en la ley mencionada, a fines de febrero de 1930 el Presidente de la República nombró jueces de indios con sede en Victoria, Nueva Imperial, Temuco, Villarrica y Valdivia ${ }^{140}$.

Sin embargo, rápidamente, la ley fue reformada, el 20 de mayo de 1931, en la misma fecha que se dictó una reforma a la ley de propiedad austral. Se estableció que la división se haría a petición de un tercio de los comuneros y no por oficio. Sucedía que, contra todo pronóstico, las comunidades se resistían a que se les impusiera una división en la que no recibían ventajas, por el tamaño de las propiedades recibidas y porque quedaban bajo la ley común, por lo que se pensó que incorporando la voluntad de la comunidad en el inicio de la partición, estas aumentarían. También en las restituciones se exigiría la petición del tercio de comuneros (jefes de familia); en este caso la exigencia venía a dificultar en vez de favorecer la recuperación de tierras. Además, para establecer los comuneros se contarían a los herederos de los mencionados en el título de merced. Por otro lado, se ampliaban las atribuciones de los jueces de indios para resolver todo lo relacionado con los títulos de merced, por ejemplo, para definir quiénes eran comuneros, los conflictos entre comunidades y entre estas y particulares. Además, se eliminó la distinción de procedimiento hecha entre los juicios de indígenas y los que afectaran a particulares; ahora todos serían resueltos como juicios sumarios. También, se redujo de tres a uno el número de abogados procuradores que auxiliaban a los indígenas en sus juicios. Para facilitar su trabajo, se concentrarían todas las apelaciones en la corte de Temuco. En otro aspecto, se le daba control al Gobierno, a través del ministerio respectivo, para resolver las contiendas que se produjeran entre jueces de indios y observar el desempeño de los mismos. Con esto se le daba una importante herramienta al Gobierno para disponer sobre estos funcionarios, además de las que ya tenía, como establecer su sede, jurisdicción, duración y personal. También, se autorizaba al Presidente de la República para excluir ciertas zonas del territorio indígena de la legislación especial, lo que dejaría, por ejemplo, la división de comunidades o las transacciones de tierras sometidas a las disposiciones comunes.

Además, se regulaba los trámites anteriores a la división. Todos estos antecedentes, junto a la sentencia definitiva de división, serían conocidos y aprobados o modificados por el ministerio respectivo. En la división serían considerados los jefes de familia o individuos, o sus sucesiones, que habitaban en la comunidad y los que se presentaren al juez. El resto serían considerados ausentes y perderían sus derechos. También, se resguardaban los derechos de las mujeres casadas en las sucesiones. La misma ley daba por válidas las divisiones de comunidades hechas con anterioridad a 1930. Por otro lado, las hijuelas de los que no quedaran conformes con la división y pidieran ser radicados, antes solo declaradas fiscales, podrían

140 Ministerio de Propiedad Austral, Boletín N ${ }^{\circ}$ 2, op. cit., 37; y Muñoz Bayer, op. cit., 39. 
ser utilizadas en beneficio de los indígenas. Además, las solicitudes de expropiación de los ocupantes no se cursarían en los casos que se refirieran a restituciones realizadas por el tribunal especial de 1927. Los indígenas que perdieran sus tierras por expropiación serían radicados como colonos. En este aspecto se corrigió a favor del indio este punto, pues se estableció que no habría expropiación cuando el ocupante no indígena tuviera una tenencia inferior a treinta años, mientras antes solo se le exigía un título anterior al de merced (que los hubo hasta 1929) y mejoras en el terreno. También, se permitió que antes de la división pudiera haber arriendo o contratos de aparcería, que los había regularmente, en la parte que el indio interesado gozara dentro de la comunidad, con un máximo de un año agrícola y previa autorización judicial. Terminada la división, los indígenas podrían celebrar todo tipo de contratos sobre sus hijuelas, con lo que se daba un permiso amplio que antes no existía, previa autorización del juez. Con el fin de incentivar las divisiones, además, quedarían exentas del pago de impuestos territoriales por cinco años las comunidades y las propiedades divididas a contar de 1930 .

Por último, se legislaba en detalle sobre la liquidación de créditos y la radicación. En lo primero, se daba competencia al juez de indios para conocer demandas por deudas de indígenas. Esto con el propósito de evitar que se les quitaran bienes a los indígenas por deudas inexistentes ante los jueces ordinarios, como ocurría tradicionalmente. En lo segundo, el juez debería darles títulos a los indígenas que ocupaban tierras fiscales, a los expropiados y a los que fueren excluidos de una comunidad por decisión del mismo juez. Con esto se activó un tema que había quedado olvidado en 1927, que debía resolverse con rapidez, dada la liberalidad con que se estaban reconociendo derechos a los particulares sobre tierras fiscales.

\section{CONCLUSIONES}

En suma, toda la acción del Estado respecto a la propiedad austral e indígena favoreció a los intereses de los propietarios rurales no indígenas. Se avalaron las usurpaciones de tierras fiscales e indígenas por particulares, se consolidaron grandes propiedades rurales y se optó por el desarrollo de la propiedad rural privada. Sin embargo, para la mayoría de los indígenas la propiedad individual no fue una opción atractiva, pues las hijuelas obtenidas eran pequeñas y estaban sujetas a la legislación común, dispuestas para ser gravadas y enajenadas. La experiencia les indicaba que era mejor formar parte de una comunidad, con todas las dificultades que ello generaba, que optar por la división.

Como se habrá notado, fue durante la dictadura de Ibáñez (1927-1931), principalmente en sus últimos meses de existencia, cuando se prepararon la mayoría de las leyes sobre la propiedad austral y las comunidades indígenas, y actuó el Ministerio de Propiedad Austral ${ }^{141}$. No es extraño, entonces, que entre los agricultores

141 Cámara de Diputados, Boletín de Sesiones, 1930, 745-748, 751-752, 1.258-1.262, 1.316-1.320, 1.598-1.601, 1.866-1.870 y 2.410-2.415; Senado, Boletín de Sesiones, 1930, 1.194-1.197; Senado, Boletín de Sesiones, 1930-1931, 24-26, 46-51, 471-474, 778-786, 985-990 y 1.015-1.019; Instituto 
del sur se guardara un buen recuerdo de este Gobierno y que Ibáñez mantuviera gran influencia política futura en la zona.

Terminada la dictadura, en julio de 1931, en medio de una profunda crisis política y económica, no hubo una modificación de las leyes comentadas, muchas de ellas dictadas por un Congreso elegido a dedo o por el propio dictador, haciendo uso de decretos con fuerza de ley. El apoyo conservador, liberal y radical, y particularmente terrateniente que las había inspirado siguió defendiendo su permanencia en los años siguientes. En los posteriores, el tema de la propiedad austral e indígena perdió prioridad y quedó subsumido dentro de otras preocupaciones.

En cuanto a las comunidades indígenas, tras el inicio de la crisis económica, por restricciones presupuestarias fueron eliminados los juzgados de indios de Valdivia y Nueva Imperial, con lo que el trabajo de los otros tres se vio incrementado. Posteriormente, el juzgado de Villarrica quedó situado en Pitrufquén. Cada uno de los juzgados terminó abarcando un territorio muy extenso: el de Victoria tenía jurisdicción sobre las comunidades de Biobío, Arauco y Malleco; el de Temuco, en Cautín, donde se hallaba la mayor parte de las comunidades; y el de Pitrufquén abarcaba parte de la provincia de Cautín y desde la provincia de Valdivia al sur. Con extensas zonas que atender, en la práctica muchos de estos jueces eran ambulantes. Materialmente, era difícil para ellos cumplir con las tareas de empadronamiento, planificación y mensura de los terrenos comunitarios, con un personal técnico limitado. A todo ello se sumaban las restituciones, radicaciones, liquidación de créditos y diversas autorizaciones que debían dar a los indígenas. Por todo esto, el cometido de los jueces de indios fue lento y difícil.

Por las dificultades que tenían los jueces de indios para realizar las particiones, por la oposición de las principales organizaciones mapuches y por el desinterés y rechazo de la mayoría de los indígenas a la propiedad privada, las divisiones no se produjeron más que en un porcentaje reducido ${ }^{142}$. De este modo, a pesar del esfuerzo del Estado y de los agricultores y comerciantes del sur de Chile, interesados por apropiarse de las tierras de las comunidades indígenas, estas permanecieron y siguieron desarrollando un importante papel en la economía de las provincias de Malleco, Cautín y Valdivia.

Nacional de Asuntos Indígenas, op. cit., 82-83, 84-87, 97-99 y 100-110; y Ministerio de Propiedad Austral, Boletín Nos 1 al 5, 1929-1930. El presidente Ibáñez no tenía una buena opinión de los indígenas. Según el obispo Guido Beck, en una entrevista con Ibáñez en 1929, este le habría dicho: "Que no consideraba justo que se lanzara a un ocupante que ha introducido en un terreno mejoras [...] para entregárselo a un indio flojo, que no hacía más que perder su tiempo en celebración de guillatunes y borracheras [...] Los indios de los alrededores de Temuco me tienen aburrido". Citado por Foerster y Montecino, op. cit., 47.

142 A principios de 1936, solo unas 47 comunidades habían sido divididas, con una superficie de 13.717 hectáreas, en las que se crearon 991 hijuelas, esto es, propiedades individuales de un promedio de 13,8 hectáreas por familia. Foerster y Montecino, op . cit., 187. 